\title{
Characterization of an Agarophyton chilense Oleoresin Containing PPAR $\gamma$ Natural Ligands with Insulin-Sensitizing Effects in a C57B1/6J Mouse Model of Diet-Induced Obesity and Antioxidant Activity in Caenorhabditis elegans
}

\author{
Claudio Pinto ${ }^{1,2}$, María Raquel Ibáñez ${ }^{3,4}$, Gloria Loyola ${ }^{3,4}$, Luisa León ${ }^{3}$, Yasmin Salvatore ${ }^{3}$, Carla González ${ }^{3}$, \\ Víctor Barraza $^{3}$, Francisco Castañeda ${ }^{5,6,7,8}$, Rebeca Aldunate ${ }^{9}$, Loretto Contreras-Porcia ${ }^{5,6,7,8(D)}$, \\ Karen Fuenzalida ${ }^{3,4, *}$ and Francisca C. Bronfman ${ }^{3,4, *}$
}

check for updates

Citation: Pinto, C.; Ibáñez, M.R.; Loyola, G.; León, L.; Salvatore, Y.; González, C.; Barraza, V.; Castañeda, F.; Aldunate, R.; Contreras-Porcia, L.; et al. Characterization of an Agarophyton chilense Oleoresin Containing PPAR $\gamma$ Natural Ligands with Insulin-Sensitizing Effects in a C57Bl/6J Mouse Model of Diet-Induced Obesity and Antioxidant Activity in Caenorhabditis elegans. Nutrients 2021, 13, 1828 . https://doi.org/10.3390/nu13061828

Academic Editor: Cristian Del Bo

Received: 31 March 2021

Accepted: 20 May 2021

Published: 27 May 2021

Publisher's Note: MDPI stays neutral with regard to jurisdictional claims in published maps and institutional affiliations.

Copyright: (C) 2021 by the authors. Licensee MDPI, Basel, Switzerland. This article is an open access article distributed under the terms and conditions of the Creative Commons Attribution (CC BY) license (https:// creativecommons.org/licenses/by/ $4.0 /)$
1 Postgraduate Department, Faculty of Veterinary Sciences, Universidad Austral de Chile, Valdivia 5110566, Chile; claudiopintovet@gmail.com

2 Center for Aging and Regeneration (CARE), Department of Cellular and Molecular Biology, Faculty of Biological Sciences, Pontificia Universidad Católica de Chile, Santiago 8320000, Chile

3 Department of Physiology, Faculty of Biological Sciences, Pontificia Universidad Católica de Chile, Santiago 8320000, Chile; raquel.ibanez@gmail.com (M.R.I.); galoyola@gmail.com (G.L.); mleon@bio.puc.cl (L.L.); ysalvatore@uc.cl (Y.S.); cdgonzalez@bio.puc.cl (C.G.); vbarraza@bio.puc.cl (V.B.)

4 Institute of Biomedical Sciences (ICB), Faculty of Medicine, Universidad Andres Bello, Santiago 8320000, Chile

5 Department of Ecology and Biodiversity, Faculty of Life Sciences, Universidad Andres Bello, Santiago 8320000, Chile; fra.castaneda@gmail.com (F.C.); lorettocontreras@unab.cl (L.C.-P.)

6 Quintay Marine Research Center (CIMARQ), Faculty of Life Sciences, Universidad Andres Bello, Valparaiso, Quintay 2480000, Chile

7 Center of Applied Ecology and Sustainability (CAPES), Santiago 8331150, Chile

8 Instituto Milenio en Socio-Ecología Costera (SECOS), Santiago 8370251, Chile

9 Faculty of Sciences, School of Biotechnology, Universidad Santo Tomas, Santiago 8320000, Chile; raldunate@santotomas.cl

* Correspondence: kfuenzalida@bio.puc.cl (K.F.); francisca.bronfman@unab.cl (F.C.B.)

Abstract: The biomedical potential of the edible red seaweed Agarophyton chilense (formerly Gracilaria chilensis) has not been explored. Red seaweeds are enriched in polyunsaturated fatty acids and eicosanoids, which are known natural ligands of the PPAR $\gamma$ nuclear receptor. PPAR $\gamma$ is the molecular target of thiazolidinediones (TZDs), drugs used as insulin sensitizers to treat type 2 diabetes mellitus. Medical use of TZDs is limited due to undesired side effects, a problem that has triggered the search for selective PPAR $\gamma$ modulators (SPPARMs) without the TZD side effects. We produced Agarophyton chilense oleoresin $\left(\right.$ Gracilex $\left.{ }^{\circledR}\right)$, which induces PPAR $\gamma$ activation without inducing adipocyte differentiation, similar to SPPARMs. In a diet-induced obesity model of male mice, we showed that treatment with Gracilex ${ }^{\circledR}$ improves insulin sensitivity by normalizing altered glucose and insulin parameters. Gracilex ${ }^{\circledR}$ is enriched in palmitic acid, arachidonic acid, oleic acid, and lipophilic antioxidants such as tocopherols and $\beta$-carotene. Accordingly, Gracilex ${ }^{\circledR}$ possesses antioxidant activity in vitro and increased antioxidant capacity in vivo in Caenorhabditis elegans. These findings support the idea that Gracilex ${ }^{\circledR}$ represents a good source of natural PPAR $\gamma$ ligands and antioxidants with the potential to mitigate metabolic disorders. Thus, its nutraceutical value in humans warrants further investigation.

Keywords: natural lipids; seaweeds; Agarophyton chilense; PPAR $\gamma$; insulin resistance; obesity; antioxidants; Caenorhabditis elegans; nutraceuticals; Gracilex ${ }^{\circledR}$

\section{Introduction}

The edible Chilean red macroalgae Agarophyton chilense (formerly Gracilaria chilensis) [1], commonly known as "pelillo", has been used as a food and medicinal herb since pre-Hispanic times in Chile, as indicated by findings at the archaeological site of Monte 
Verde ( 14,000 years ago) [2]. Agarophyton chilense (A. chilense) is distributed in New Zealand (including Chatham Island) and South America [3-6], and although this species has good nutritional potential, it is mainly exploited for the extraction of agar-agar, a hydrocolloid $[7,8]$.

The reported bioactivity of seaweed is varied and includes antidiabetic, antiinflammatory, antioxidant, and anti-neurodegenerative activity $[9,10]$. Thus, in recent years, there has been increased interest in identifying novel bioactive compounds that demonstrate health benefits to confirm and increase the added value of edible red seaweeds $[8,11]$.

Red algae such as $A$. chilense are an excellent source of healthy essential fatty acids such as polyunsaturated fatty acids (PUFAs), including eicosapentaenoic acid, arachidonic acid, and oleic, linoleic, and $\alpha$-linolenic fatty acids. Particularly in the Gracilaria genus, lipid extraction has revealed a complex lipid composition of glycerolipids and omega-3 and omega-6 PUFAs and their oxidized derivatives, known as oxylipins [12-15]. Oxylipins are synthesized either by the metabolic action of specific lipoxygenases (LOXs) or by nonenzymatic reactions on PUFAs [16-18]. Interestingly, the oxylipin structure is similar or equivalent to that of mammalian prostaglandins, leukotrienes, and eicosanoids [19], which are well-known ligands of peroxisome proliferator-activated receptors (PPARs) [20-22].

The PPAR nuclear receptor subfamily comprises three receptor subtypes (PPAR $\alpha$, $\operatorname{PPAR} \beta / \partial$, and PPAR $\gamma$ ) encoded by distinct genes, and they are obligate heterodimers of the RXR receptors [23]. PPARs have attracted increased attention as therapeutic targets given the physiological relevance of the processes in which they are involved, including lipid and glucose homeostasis, and because they have anti-inflammatory and antioxidant activity [23-26]. The three PPARs have natural ligands, including PUFAs and eicosanoids [27-31]. All of these lipids activate PPARs with low affinity (micromolar range) compared to high-affinity synthetic agonists such as fibrates and thiazolidinediones (TZDs). In particular, fibrates, which are drugs used to treat dyslipidemia, target PPAR $\alpha[26,32]$ while TZDs act as full agonists of PPAR $\gamma$. TZDs were designed in the late 1990s for the treatment of type 2 diabetes mellitus (T2DM), to regulate blood sugar levels and improve insulin sensitivity in patients with, and animal models of, T2DM [33]. However, in early 2007, the adverse effects of these drugs, including weight gain, fluid retention, osteoporosis, and heart failure, among others, were described [33-35]. These side effects have led to restricted access in the United States and a recommendation for removal from the market in Europe and other jurisdictions [36]. At the molecular level, TZDs, such as rosiglitazone, stabilize the ligand-binding site of PPAR $\gamma$ in an "on" or "off" state. In contrast, selective PPAR $\gamma$ modulators (SPPARMs) generate various dynamic and slow conformational changes by recruiting different coactivators and corepressors compared to TZDs, thus inducing a different gene expression profile and reduced side effects compared to TZDs [37].

T2DM is a chronic endocrine disease characterized by hyperglycemia in the blood and resistance to the action of insulin, leading to severe neurological and cardiovascular lesions. Although there are genetic risk factors, obesity is considered the explaination for $60-80 \%$ of diabetes cases [38-40].

There are various classes of oral drugs for glycemic management, such as metformin, sulfonylureas, and TZDs. Currently, the first-line oral antihyperglycemic is metformin. However, the majority of patients with T2DM show a deterioration in blood glucose levels over time that cannot be controlled with metformin alone; consequently, a second-line drug to maintain glycemic control is included in the treatment [41,42]. Recently, the use of nutraceuticals, such as berberine extracts and omega- 3 fatty acids, was suggested for the management of glycemia and dyslipidemia associated with T2DM [43]. Experts have emphasized the use of nutraceuticals and functional foods to treat or mitigate T2DM based on the advantages of using a mix of molecules with simultaneous effects. The Asian continent is familiar with medicine derived from natural products. Therefore, interest in the use of nutraceuticals, including products derived from the sea such as seaweeds [44], for the treatment of T2DM has increased [45]. 
Despite the rich diversity of lipids and the unique phytochemical composition of red macroalgae lipids, the biomedical potential of lipids derived from $A$. chilense has not been addressed. The principal objective of our work was to study the biomedical potential of $A$. chilense oleoresin by evaluating its capacity to activate PPAR $\gamma$ and modulate the metabolic dysfunction induced by obesity. We also characterized some of the lipids contained in the oleoresin, such as fatty acids, tocopherols, and $\beta$-carotene, and the antioxidant properties in vitro and in vivo using Caenorhabditis elegans (C. elegans) as a model. The oleoresin was produced by organic solvent extraction of dried algae following the procedure published in the patent application WO/2014/186913, and its trademark registered name is Gracilex ${ }^{\circledR}$. Our results indicate that Gracilex ${ }^{\circledR}$ contains PPAR $\gamma$ activators acting as partial agonists, since they do not induce adipocyte differentiation like the TZD rosiglitazone. Consistently, treatment of male mice fed a high-fat diet (HFD) with Gracilex ${ }^{\circledR}$ reduced glucose and insulin levels increased by the HFD. Moreover, Gracilex ${ }^{\circledR}$ has an antioxidant capacity correlating with high levels of tocopherols and $\beta$-carotene. Our study is the first to examine whether lipids derived from $A$. chilense have nutraceutical or biomedical applications, emphasizing the idea that $A$. chilense can be used as a source of other molecules in addition to agar-agar.

\section{Material and Methods}

\subsection{Reagents}

HPLC-grade dichloromethane, cyclohexane, and water were purchased from Merck (Darmstad, Germany). Cell culture reagents, namely Dulbecco's Modified Eagle Medium (DMEM), RPMI 1640, opti-PRO ${ }^{\mathrm{TM}}$, GlutaMAX ${ }^{\mathrm{TM}}$ I supplement, Tripsin-EDTA $0.5 \%$, and penicillin/streptomycin, were purchased from Gibco BRL (Life Technologies, Inc., Gaithersburg, MD, USA). Fetal bovine serum and horse serum (HS) were obtained from HyClone Laboratories, Inc. (Thermo Fisher Scientific, Waltham, MA, USA) and Lipofectamine ${ }^{\mathrm{TM}}$ 2000 from Gibco BRL (Life Technologies, Waltham, MA, USA). Drugs and chemicals were purchased from Sigma Chemical Co. (St. Louis, MO, USA), including FMOC-Leu, 3-(4,5-dimethylthiazol-2-yl)-2,5-diphenyl tetrazolium bromide (MTT), ortho-nitrophenyl$\beta$-galactoside (ONPG), N-acetylcysteine (NAC), cell culture grade dimethyl sulfoxide (DMSO), NP-40, Oil red O, dexamethasone, isobutylmethylxanthine (IBMX), and insulin. Rosiglitazone and T0070907 were purchased from Cayman Chemicals (Ann Arbor, MI, USA) and INT131 was obtained from MolPort (Beacon, NY, USA). FMOC-Leu and INT131 are SPPARMs and rosiglitazone and T0070907 are full-agonist and antagonist of the PPAR $\gamma$, respectively.

Plasmids used to measure the transcriptional activity of PPAR $\gamma$ (see below) were donated by R.M. Evans's laboratory (Howard Hughes Medical Institute, Gene Expression Laboratory, The Salk Institute for Biological Studies, La Jolla, CA, USA).

\subsection{Sampling of Biomass}

Vegetative A. chilense individuals, approximately $60 \mathrm{~cm}$ in length, were collected from two areas along the Chilean coast in the southern zone: Niebla $\left(39.87^{\circ} \mathrm{S} 73.40^{\circ} \mathrm{W}\right.$, Los Lagos Region) and Coliumo ( $36.55^{\circ} \mathrm{S} 72.95^{\circ} \mathrm{W}$, Biobío Region). The total biomass (20-30 kg of fresh tissue) was transported to the laboratory at $4{ }^{\circ} \mathrm{C}$ and washed with fresh water posteriorly with $1 \mu \mathrm{m}$ filtered seawater and cleaned before freezing.

\subsection{Oleoresin Analysis}

\subsubsection{A. Chilense $\left(\right.$ Gracile $\left.^{\circledR}\right)$ Oleoresin Production}

Harvested seaweed was frozen at $-20{ }^{\circ} \mathrm{C}$ for two weeks and then chopped into small pieces (3-5 $\mathrm{mm}$ in length) with a knife for the production of oxylipins induced by algal tissue after mechanical damage [16]. Chopped algae were freeze-dried through lyophilization. Then, to produce a lyophilized powder, the dried material was ground using a coffee grinding machine. Dichloromethane was used as an organic solvent for lipid extraction of pulverized dried seaweed. In brief, $50 \mathrm{~g}$ of pulverized dry alga was 
placed in an Erlenmeyer flask with $150 \mathrm{~mL}$ of dichloromethane, shaken for $30 \mathrm{~min}$, and filtered. The remaining sediment was extracted once again as indicated above. The whole filtered extract was evaporated, suspended in cyclohexane, and lyophilized to finally obtain an oleoresin of $A$. chilense, whose trademark registered name is Gracilex ${ }^{\circledR}$. The detailed protocol is published in the patent application $\mathrm{WO} / 2014 / 186913$ [46].

\subsubsection{Determination of Total Antioxidant Capacity of Gracilex ${ }^{\circledR}$ Using a Cupric Ion} Reducing Antioxidant Capacity (CUPRAC) Assay

Oleoresins obtained from dichloromethane extraction of lyophilized spirulina (AquaSolar ${ }^{\mathrm{TM}}$ ) and maqui (Isla Natura ${ }^{\mathrm{TM}}$ ) were prepared as described above for Gracilex ${ }^{\circledR}$ production. The oleoresins were resuspended in DMSO, and $50 \mu \mathrm{L}$ of sample was taken to measure the antioxidant capacity using an OxiSelect ${ }^{\mathrm{TM}} \mathrm{TAC}$ Assay Kit according to the manufacturer's instructions (Cell Biolabs, Inc., San Diego, CA, USA), which is based on the reduction of copper (II) to copper (I), also known as a cupric ion reduction antioxidant capacity (CUPRAC) assay [47]. Uric acid was used as a standard to calculate the milli-equivalents of antioxidant.

\subsubsection{Analysis of Lipid and Antioxidant Content of Gracilex ${ }^{\circledR}$}

Six preparations of Gracilex ${ }^{\circledR}$ were used to measure tocopherols $(\alpha-, \gamma-$, and $\delta$ tocopherol) and $\beta$-carotene by HPLC-electrochemical methods. The fatty acid profile of Gracilex ${ }^{\circledR}$ was measured as fatty acid methyl esters by GC-FID. Both analyses were performed at the Center of Molecular Nutrition and Chronic Disease of Pontificia Universidad Católica de Chile according to the Chilean normative procedure NCh2550-ISO5508.

\subsection{Cellular Studies}

\subsubsection{Cell Lines}

HeLa $\left(\right.$ ATCC $^{\circledR}$ CCL- $^{\text {TM }}$ ), PC12 $\left(\right.$ ATCC $^{\circledR}$ CRL-172 ${ }^{\mathrm{TM}}$ ), and 3T3-L1 $\left(\right.$ ATCC $^{\circledR}$ CL-173 ${ }^{\mathrm{TM}}$ ) cell lines (ATCC, Manassas, VA, USA) were used for our studies. All cells were cultured, following ATTC's recommendations, in a $5 \% \mathrm{CO}_{2}$ incubator at $37^{\circ} \mathrm{C}$ and $95 \%$ humidity.

PC12 cells were grown and cultured in RPMI 1640 medium supplemented with $10 \%$ horse serum (HS), 5\% fetal bovine serum (FBS), and penicillin/streptomycin (P/S). HeLa and 3T3-L1 cells were grown and cultured in high-glucose DMEM with $10 \%$ and P/S. The 3T3-L1 cells were grown under low passages at a maximum of 70\% confluence.

\subsubsection{Cellular Transfection}

A PPAR reporter activity assay was performed by transient transfection of PC12 and HeLa cells with a reporter plasmid containing three tandem repeats of the peroxisomal proliferator response element (PPRE) fused to the herpesvirus thymidine kinase promoter upstream of the coding sequence for luciferase (PPRE-tk-LUC) and a PCMX vector containing full-length murine PPAR $\gamma 1$ [48]. Cells were grown until $60-70 \%$ confluence in 24-well collagen-coated plates and transfected with $2 \mu \mathrm{L}$ of Lipofectamine ${ }^{\mathrm{TM}} 2000$ (Thermo Fisher, Waltham, MA, USA) and $0.3 \mu \mathrm{g}$ of PPRE-tk-LUC vector, $0.26 \mu \mathrm{g}$ of pCMX-PPAR $\gamma$ vector, and $0.1 \mu \mathrm{g}$ of $\beta$-galactosidase expression plasmid (CMV- $\beta$-Gal) vector (Clontech, now Takara Bio USA Inc., Mountain View, CA, USA) for normalization.

A PPAR $\gamma$-GAL4 transactivation assay was performed in PC12 cells seeded in 48well plates at a density of $1 \times 10^{5}$ cells/well in $250 \mu \mathrm{L}$ of RPMI 1640 medium (10\% HS, $5 \% \mathrm{SFB}$, and P/S) grown for $24 \mathrm{~h}$ and transfected with Lipofectamine ${ }^{\mathrm{TM}} 2000$ (Thermo Fisher, Waltham, MA, USA) with $0.8 \mu \mathrm{g}$ of reporter plasmid (Gal4-dependent MH100tkLuc), $0.8 \mu \mathrm{g}$ of fusion protein plasmid (PPAR $\gamma$ GAL4), and $0.053 \mu \mathrm{g}$ of CMV- $\beta$-Gal as an internal control [49,50]. Transfection was carried out in low-serum RPMI 1640 medium ( $2 \%$ SFB and $2 \%$ HS) without antibiotics for $6 \mathrm{~h}$, the medium was replaced, and the cells were treated with the indicated extracts and corresponding vehicle for $16 \mathrm{~h}$. The medium was then discarded and the cells were lysed with reporter lysis buffer (Cell Culture Lysis buffer, Promega, Madison, WI, USA). The lysate was centrifuged, and the luciferase activity 
of the supernatant was determined using a luciferase assay system (Promega, Madison, WI, USA) and measured in a luminometer (Turner Biosystem 20/20). For normalization of luciferase activity, $\beta$-galactosidase activity was evaluated using o-nitrophenyl- $\beta$-Dgalactopyranoside (ONPG) as the substrate in a standard colorimetric enzymatic assay. The luminescence signals obtained from the luciferase activity measurements were normalized to $\beta$-galactosidase colorimetric measurements to account for differences in the transfection efficiency or cell number. All transfection experiments were performed in triplicate.

\subsubsection{Adipocyte Differentiation}

The 3T3-L1 cells were differentiated as described previously [51]. Briefly, 3T3-L1 cells were seeded in DMEM with $10 \%$ FCS at a density of $6 \times 10^{5}$ cells $/ 35 \mathrm{~mm}$ plate for lipid staining or $2 \times 10^{5}$ cells $/ 12$-well plate for RNA extraction. After $48 \mathrm{~h}$, the differentiation medium was used, containing freshly prepared solutions of $1 \mu \mathrm{g} / \mathrm{mL}$ insulin, $0.5 \mathrm{mM}$ isobutylmethylxanthine (IBMX), and $0.1 \mu \mathrm{g} / \mathrm{mL}$ dexamethasone in the presence or absence of the test compound RGZ $(1 \mu \mathrm{M})$, FMOC-Leu $(25 \mu \mathrm{M})$, or Gracilex ${ }^{\circledR}(60 \mu \mathrm{g} / \mathrm{mL})$. After $48 \mathrm{~h}$, the differentiation medium was replaced with DMEM containing $1 \mu \mathrm{g} / \mathrm{mL}$ insulin, then the medium was changed to DMEM supplemented with 10\% FBS and P/S. Every 2 days the medium was changed. After 7 days of differentiation, the cells were harvested for RNA extraction using a HiBind column (Omega Bio-Tek, Norcross, GA, USA) following the manufacturer's instructions. On the tenth day of differentiation, the cells were stained with Oil Red O, as described previously. Briefly, the cells were washed twice with PBS at $37^{\circ} \mathrm{C}$ and then fixed with $4 \%$ paraformaldehyde (PFA) for $1 \mathrm{~h}$ at room temperature. The plate was washed with PBS and treated with $60 \%$ isopropyl alcohol for $6 \mathrm{~min}$. After the plates were dried, Oil Red O (6:4) was added for $2 \mathrm{~h}$ at room temperature. Subsequently, the plates were washed extensively, dried, and photographed. For quantification of Oil Red O incorporation in cells, cells fixed in the plates were solubilized with pure isopropyl alcohol, and the absorbance of the solution was measured at $490 \mathrm{~nm}$ [52].

\subsubsection{MTT Viability Assay}

A 3-(4,5-dimethylthiazol-2-yl)-2,5-diphenyl tetrazolium bromide (MTT) assay was performed in PC12 cells as described previously, with minor modifications [53]. Briefly, PC12 cells were seeded in 48-well plates at a density of $1.5 \times 10^{5}$ cells/well in $250 \mu \mathrm{L}$ of RPMI 1640 medium (10\% HS, 5\% SFB, and P/S) and grown for $24 \mathrm{~h}$. Then, the medium was replaced with a low-serum RPMI 1640 medium ( $2 \%$ SFB, 2\% HS, and Ab-Am).

The 3T3-L1 cells were seeded in 48-well plates at a density of $9 \times 10^{4}$ cells/well in $250 \mu \mathrm{L}$ of DMEM (10\% CS and Ab-Am) and grown for $24 \mathrm{~h}$. The cells were treated with the indicated extracts and corresponding vehicle for $16 \mathrm{~h}$. The cells were washed with PBS and then incubated with $0.5 \mathrm{mg} / \mathrm{mL}$ MTT dissolved in a medium without phenol red or serum for $2 \mathrm{~h}$ at $37^{\circ} \mathrm{C}$. The MTT solution was discarded, and the cells were lysed with pure DMSO. The formazan product was measured in a spectrophotometer at 570 and $620 \mathrm{~nm}$. The difference between the two measurements was used to calculate the percentage of cell survival with respect to the control.

\subsubsection{RT-qPCR}

The RNA quality was evaluated by agarose gel integrity. Any contaminant genomic DNA was degraded by DNase treatment (RQ1, RNase-free DNase, Promega, Madison, WI, USA). The cDNA was generated using M-MLV reverse transcriptase (Promega, Madison, WI, USA) and random primers, while the qPCR was performed using SYBR Green (Brilliant II SYBR Green qPCR Mastermix, Agilent Technologies, Santa Clara, CA, USA) in a Stratagene MX-3000P qPCR System (Agilent Technologies). Fatty acid binding 4 (Fabp4) and lipoprotein lipase $(\mathrm{Lpl})$ genes were amplified together with 3 reference genes in each run: glyceraldehyde-3-phosphate dehydrogenase (GAPDH), NoNo, and $\beta$-actin. The murine primer sequences used for Fabp4 were F: $5^{\prime}$-GCGTGGATTTCGATGAAATCA-3' and R: $5^{\prime}-$ CCCGCCATCTAGGGTTATGA-3'; for Lpl, F: $5^{\prime}$-ATTTGCCCTAAGGACCCCTG-3' and R: 
5'-GCACCCAACTCTCATACATTCC-3' ; for GAPDH, F: 5' -TGCACCACCAACTGCTTAGC$3^{\prime}$ and R: $5^{\prime}$-GGATGCAGGGATGATGTTCT- $3^{\prime}$; for NoNo, F: $5^{\prime}$-TGCTCCTGTGCCACCTGG TACTC-3' ${ }^{\prime}$ R: 5'-CCGGAGCTGGACGGTTGAATGC-3'; and for $\beta$-actin, F: $5^{\prime}$-CCTGTGCTG CTCACCGAGGC-3' ${ }^{\prime}$ and R: $5^{\prime}$-GACCCCGTCTCCGGAGTCCATC- $3^{\prime}$.

\subsection{Mouse Studies}

\subsubsection{Mouse Treatments}

C57BL/6J mice were maintained with water and food supplied ad libitum at the Pontificia Universidad Católica de Chile Catholic University animal facility. The mice were housed in a room with controlled temperature $\left(24^{\circ} \mathrm{C}\right)$ and humidity $(55-60 \%)$ for a $12 \mathrm{~h}$ light and dark regime. All procedures were performed during the dark phase. Experimental protocols were approved by the biosafety and bioethics committee of the Pontificia Universidad Católica de Chile (project FONDEF\#DO811031). All animal procedures were conducted according to the National Agency of Research and Development (ANID) guidelines.

To study Gracilex ${ }^{\circledR}$ toxicity, 12 adult C57BL/6J mice (12 weeks old) from our animal facility were fed with a standard chow diet and corn oil (control) or Gracilex ${ }^{\circledR}(300 \mathrm{mg} / \mathrm{kg}$ ) for 15 days (see below in histopathological studies).

For high-fat diet experiments, 50 adult C57BL/6J mice (6 weeks old) were imported from the Jackson Laboratory (USA). At 6 weeks of age, the mice were separated into 5 groups of 10 animals: 4 groups were fed the high-fat diet (HFD: $60 \% \mathrm{kcal}$ based on fat, Research Diets, Inc., New Brunswick, NJ, USA), and 1 group was fed the low-fat diet (LFD: $10 \%$ kcal based on fat) $[54,55]$.

The animals were weighed twice a week throughout the study. At 12 weeks of age, the mice were treated as follows: control diet (LFD) mice were treated with corn oil, control HFD mice were treated with corn oil, positive control HFD mice were treated with rosiglitazone $(5 \mathrm{mg} / \mathrm{kg})$, and HFD mice were treated with two doses of Gracilex ${ }^{\circledR}, 90$ and $300 \mathrm{mg} / \mathrm{kg}$. The treatment was administered once a day by oral gavage for 30 days. The daily volume administered was approximately $50 \mu \mathrm{L}$.

\subsubsection{Measurement of Plasma Metabolic Parameters}

Blood samples were obtained at the beginning and end of the treatment (12 and 16 weeks old, respectively). Before sampling, the mice were fasted for $15 \mathrm{~h}$. Samples were obtained by puncture of the submandibular sinus, collected in heparinized tubes, and immediately centrifuged $\left(3500 \mathrm{rpm} / 10 \mathrm{~min}\right.$ at $4{ }^{\circ} \mathrm{C}$ ) to obtain blood plasma.

Mouse adiponectin (DuoSet ${ }^{\circledR}$ R\&D Systems, MN, USA) and mouse insulin (Ultrasensitive EIA, ALPCO Diagnostic, NH, USA) were detected by ELISAs. Plasma levels of glucose and cholesterol were determined by enzymatic chemical kits (Wiener Laboratories SAIC, Buenos Aires, Argentina).

\subsubsection{Histopathological Studies}

Twelve C57BL/6J mice (12 weeks old) per experimental group were randomly assigned to treatment with either corn oil (control) or Gracilex ${ }^{\circledR}(300 \mathrm{mg} / \mathrm{kg})$. The treatment was administered once a day by oral gavage for 15 days. The daily volume administered was approximately $50 \mu \mathrm{L}$. At the end of the treatment, the mice were euthanized by isoflurane overdose. The liver, kidney, esophagus, and stomach were extracted and maintained in $9.25 \%$ formalin $\left(4^{\circ} \mathrm{C}\right)$ for $48 \mathrm{~h}$. For histopathological evaluation, samples were embedded in paraffin, processed under standard conditions, and stained with hematoxylin-eosin. Liver fat accumulation was determined by Sudan black staining, and liver glycogen deposition and kidney basal membrane were evaluated by Schiff's periodic acid (SPA) staining. The histopathological findings were classified according to magnitude $(0=$ absent; I $=$ slight; II = moderate; and III = severe). 


\subsection{Elegans Studies}

Nematodes were cultivated at $20^{\circ} \mathrm{C}$ under standard laboratory conditions on agar plates fed with Escherichia coli (OP50) as a food source [56]. The oxidative stress-sensitive msra-1(tm1421) mutant strain [57] was used for stress resistant assays. Prior to the oxidative stress challenge, the nematodes were fed for $24 \mathrm{~h}$ with Gracilex ${ }^{\circledR}$ or its vehicle DMSO. For administration to nematodes, plates were prepared as follows: Gracilex ${ }^{\circledR}$ was dissolved in DMSO at a concentration of $100 \mathrm{mg} / \mathrm{mL}$. A stock of dead bacteria was prepared by growing the E. coli OP50 strain in lithium borate (LB) buffer overnight. After centrifugation, the pellet was resuspended to obtain a stock concentrated six times. This stock was heated at $70{ }^{\circ} \mathrm{C}$ for $30 \mathrm{~min}$ and stored at $-20^{\circ} \mathrm{C}$ until use. Then, $25 \mu \mathrm{g}$ of Gracilex ${ }^{\circledR}$ was mixed with $50 \mu \mathrm{L}$ of dead bacteria and NP40 to a final concentration of $0.1 \%$ and a final volume of $52 \mu \mathrm{L}$. This mix was seeded on $2 \mathrm{~mL}$ of nematode growth medium (NGM) agar plates (35 mm). The plates were left to dry in the dark overnight in the laminar flow chamber and stored at $4{ }^{\circ} \mathrm{C}$ in the dark for no more than 1 week before use. For the oxidative stress test, L4 stage $m s r a-1$ nematodes were grown for $24 \mathrm{~h}$ on plates with Gracilex ${ }^{\circledR}$ or DMSO (vehicle). On the day of the test, the nematodes were transferred to a 24-well plate containing $600 \mu \mathrm{L}$ of $9 \mathrm{mM}$ hydrogen peroxide dissolved in $\mathrm{M} 9$ medium (minimal medium containing minimal salts: $\mathrm{KH}_{2} \mathrm{PO}_{4} 15 \mathrm{~g} / \mathrm{L}, \mathrm{NaCl} 2.5 \mathrm{~g} / \mathrm{L}, \mathrm{Na}_{2} \mathrm{HPO}_{4} 33.9 \mathrm{~g} / \mathrm{L}$, and $\mathrm{NH}_{4} \mathrm{Cl}$ $5 \mathrm{~g} / \mathrm{L}$ ). Ten nematodes were placed per well, and the movement was monitored every $10 \mathrm{~min}$ as described in [58] until there was no living nematode (approximately $2 \mathrm{~h}$ ). Each experiment was performed in triplicate (30 nematodes per condition) [59].

\subsection{Statistical Analysis}

Cell-based assays for PPAR $\gamma$ transactivation were performed in triplicate and at least three independent experiments. The results were expressed as the mean fold change in induction relative to the control condition \pm SEM. One-way analysis of variance (ANOVA) followed by Tukey's multiple comparison test, was applied to determine statistical significance between the control and treatment conditions. The same statistical tests were used for the analysis of 3T3-L1 cell differentiation in the Oil Red O assay and in lipogenic gene mRNA induction as determined by qPCR. For the in vivo studies of insulin resistance, an unpaired $t$-test was used to compare the low-fat and high-fat diet groups. For analysis of the differences between subgroups of HFD-fed and LFD-fed mice, a one-way ANOVA and Tukey's multiple comparison test were applied. Finally, in C. elegans in vivo experiments, a two-way ANOVA with repeated measures was used to compare differences in the survival curves of the nematodes fed Gracile ${ }^{\circledR}$ and those under control conditions. Fisher's LSD post-test was used to determine significant differences at appropriate times. Significant differences were calculated at significance levels indicated as: ${ }^{*} p<0.5,{ }^{* *} p<0.01$, and *** $p<0.001$. Statistical analysis was performed using GraphPad Prism 5.0 for Mac (GraphPad Software, San Diego, CA, USA). We analyzed the data for outliers using the Grubbs method (GraphPad Software). We detected just one outlier in the experimental point Gracilex ${ }^{\circledR}+$ T007 of Figure 1C. Accordingly, we removed this point from the graph. We did not detect other outliers in the rest of the figures. 
A

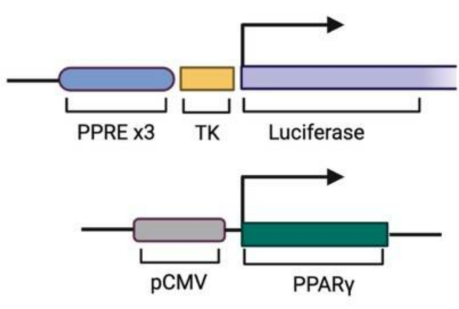

B

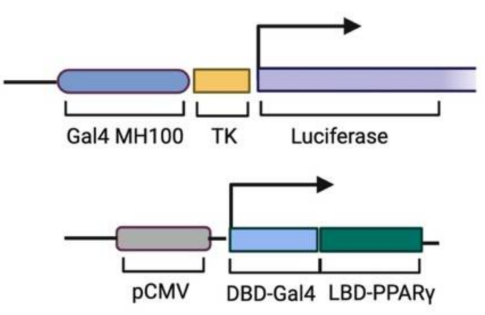

PC12 cells

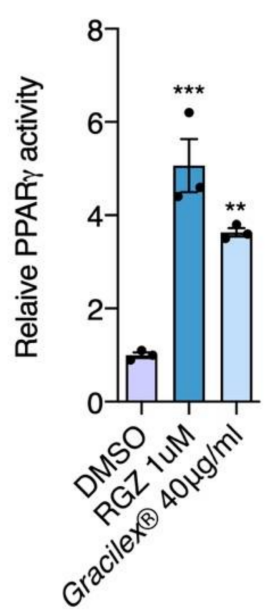

HeLa cells

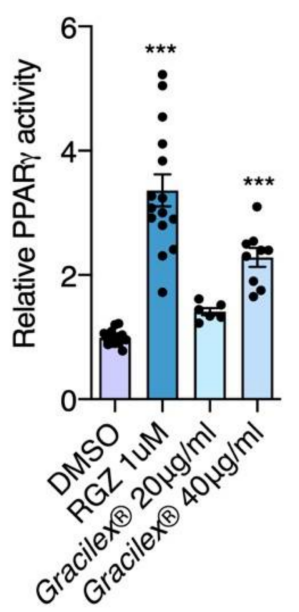

C
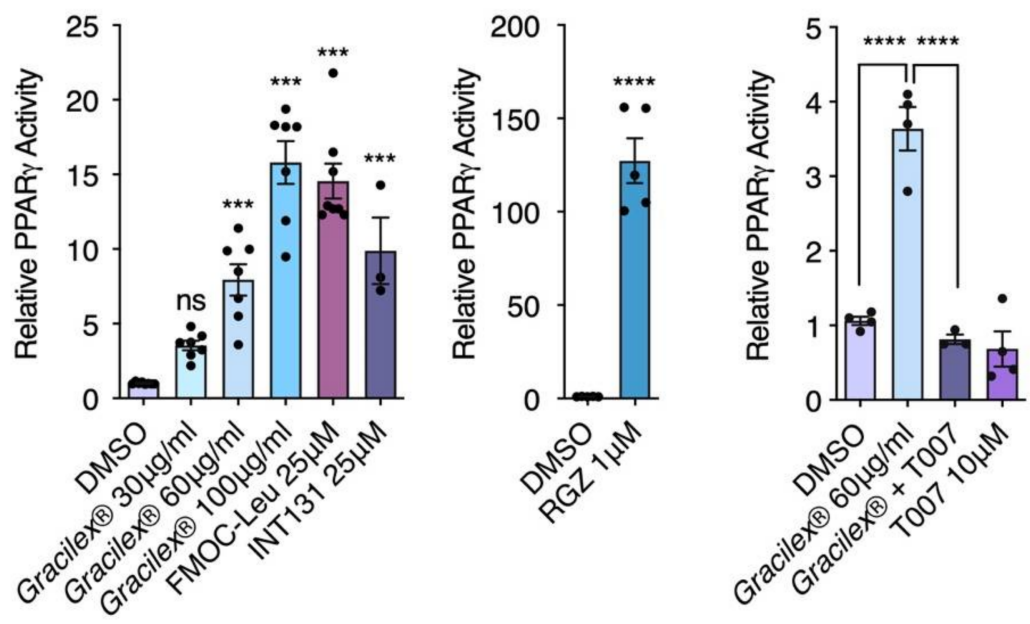

Figure 1. Agarophyton chilense oleoresin $\left(\right.$ Gracilex $\left.^{\circledR}\right)$ induces PPAR $\gamma$ transcriptional activation. Two cell-based reporter assays to measure PPAR $\gamma$ activation were performed. Left panel (A): schematic representation of vectors used for cotransfection. PC12 and HeLa cells were cotransfected with plasmids expressing full-length murine PPAR $\gamma$ and a reporter plasmid containing PPRE (peroxisomal proliferator response element) driving expression of luciferase, together with plasmid expressing beta-galactosidase as transfection control. Full PPAR $\gamma$ agonist rosiglitazone (RGZ, $1 \mu \mathrm{M})$ and Gracilex ${ }^{\circledR}$ $(40 \mu \mathrm{g} / \mathrm{mL})$ induced transcriptional activation of PPAR $\gamma$, as shown by increased luciferase activity normalized to betagalactosidase expression (expressed as relative PPAR $\gamma$ activity). In PC12 cells $(n=3)$ and HeLa cells $(n=6-13)$, treatments (RGZ and Gracilex ${ }^{\circledR}$ ) were compared to control transfected cells (DMSO), and values are presented as \pm SEM, ${ }^{* *} p<0.01$, and ${ }^{* * *} p<0.001$ (one-way ANOVA and Tukey's post hoc test). Left panel (B): schematic representation of vectors used for cotransfection. Plasmid with expression of a chimeric construct of PPAR $\gamma$ ligand binding domain (LBD-PPAR $\gamma$ ) gene and DNA binding domain of Gal4 (DBD-Gal4) was cotransfected with a plasmid possessing the response element of GAL4 (Gal4 MH100) driving luciferase expression. As in (A), a third plasmid was included with expression of beta-galactosidase as transfection control. Increased PPAR $\gamma$ activation is expressed as relative PPAR $\gamma$ activity. Gracilex ${ }^{\circledR}$ induced dose-response activation of PPAR $\gamma$ is comparable to activation induced by selective PPAR modulators (SPPARMs) of PPAR $\gamma$, FMOC-Leu, and INT131 at a concentration of $25 \mu \mathrm{M}$. Instead, RGZ at $1 \mu \mathrm{M}$ shows much higher activation (110 times over control), as expected for a full agonist. Values are presented as \pm SEM, $n=3-7$, and ${ }^{* * *} p<0.001,{ }^{* * * *} p<0.0001$ left panel: one-way ANOVA and Tukey's post hoc test; right panel: unpaired $t$-test). The (C) PC12 cells were transfected as described in (B) and treated with Gracilex ${ }^{\circledR}(60 \mu \mathrm{g} / \mathrm{mL})$ with or without PPAR $\gamma$ antagonist T0070907 (T007, $\left.10 \mu \mathrm{M}\right)$. Values are presented as $\pm \mathrm{SEM}, n=4$, and ${ }^{* * * *} p<0.0001$ (one-way ANOVA and Tukey's post hoc test). 


\section{Results}

\subsection{Effect of Gracilex ${ }^{\circledR}$ on PPAR $\gamma$ Transcriptional Activity}

To determine whether Gracilex ${ }^{\circledR}$ can induce transcriptional activation of PPAR $\gamma$, we used two cell lines, HeLa and PC12, for transient transfection assays using the PPRE-tkLUC reporter [60] cotransfected with the PPAR $\gamma$ expression vector (Figure 1A). In both cell types, Gracilex ${ }^{\circledR}$ induced significant activity at $40 \mu \mathrm{g} / \mathrm{mL}$, resulting in up to $65 \%$ of the maximal activation achieved by the full agonist rosiglitazone at $1 \mu \mathrm{M}$. To further confirm the activation of PPAR $\gamma$ by lipids derived from Gracilex ${ }^{\circledR}$ and to study the contribution of PPAR $\gamma$ to the increased luciferase, we assessed the ability of Gracile ${ }^{\circledR}$ to activate the chimeric GAL4-DBD-PPAR-LBD protein from a Gal4-dependent MH100-Luc reporter using PC12 cells (Figure 1B). In this assay, the reporter was activated by the chimeric GAL4-DBD fusion protein, thus avoiding potential interference from any endogenous receptor $[49,50]$. We observed dose-response activation of PPAR $\gamma$ with Gracilex ${ }^{\circledR}$. At a concentration of $100 \mu \mathrm{g} / \mathrm{mL}$, Gracilex ${ }^{\circledR}$ showed PPAR $\gamma$ activity induction comparable to that promoted by the SPARMs INT131 and FMOC-Leu at $25 \mu \mathrm{M}$ (Figure 1B). In contrast, rosiglitazone-induced PPAR $\gamma$ activation was over 8 times higher at $1 \mu \mathrm{M}$ compared to Gracilex ${ }^{\circledR}$, which is consistent with the definition of a full agonist (Figure 1B). The PPAR $\gamma$ activation induced by Gracilex ${ }^{\circledR}$ was prevented upon cotreatment with the PPAR $\gamma$ antagonist T0070907 [61], demonstrating that Gracilex ${ }^{\circledR}$ specifically activates PPAR $\gamma$ (Figure 1C). These results suggest that Gracilex ${ }^{\circledR}$ is a good source of natural ligands for PPAR $\gamma$. No effects on the survival of PC12 cells were observed for any of the Gracilex ${ }^{\circledR}$ concentrations evaluated (Supplementary Figure S1A).

SPPARMs are selective modulators of PPAR $\gamma$ activity with partial agonism and reduced side effects, such as adipose tissue gain [62]. Considering that PPAR $\gamma$ is a master gene for adipocyte differentiation and Gracilex ${ }^{\circledR}$ activates PPAR $\gamma$ similarly to SPPARM at the higher doses evaluated $(60$ and $100 \mu \mathrm{g} / \mathrm{mL}$ ), we next characterized the effect of Gracile ${ }^{\circledR}$ on the adipocyte differentiation of 3T3-L1 cells using a well-established protocol [51]. Incubation of the 3T3-L1 cell line with rosiglitazone $(1 \mu \mathrm{M})$ and a hormonal mix for 7 days induced an evident increase in Oil Red O staining, which labels lipid droplets, indicating the accumulation of triglycerides [63]. Quantification of the isopropanol soluble fraction [52], derived from 3T3-L1 differentiated cells by absorbance at $490 \mathrm{~nm}$, showed a twofold increase in cells treated with rosiglitazone compared to cells treated with only the hormonal mixture (Figure 2A,B). In contrast, neither FMOC-Leu or INT131 at $25 \mu \mathrm{M}$ nor Gracilex ${ }^{\circledR}$ at $60 \mu \mathrm{g} / \mathrm{mL}$ mimicked the effects of rosiglitazone (Figure $2 \mathrm{~A}, \mathrm{~B}$ ). To further confirm that SPPARMs and Gracile ${ }^{\circledR}$ would not induce adipose differentiation, we measured the induction of mRNA levels of the adipogenic marker genes lipoprotein lipase (LPL) and fatty acid binding protein 4 (FABP4). We observed that only rosiglitazone promoted the adipocyte differentiation program in 3T3-L1 cells (Figure 2C). To uncover the possible toxic effects of Gracilex ${ }^{\circledR}$ in differentiated 3T3-L1 cells, we determined cell viability by MTT assay after Gracilex ${ }^{\circledR}$, FMOC-Leu, INT131, or rosiglitazone treatment. No changes in cell survival were found for PPAR $\gamma$ agonists in 3T3-L1 cells (Supplementary Figure S1B). Taken together, these results indicate that Gracilex ${ }^{\circledR}$ can induce PPAR $\gamma$ activation in a similar fashion to SPPARMs without promoting adipocyte differentiation (or toxic effects) in 3T3-L1 cells at the concentration used. 
A

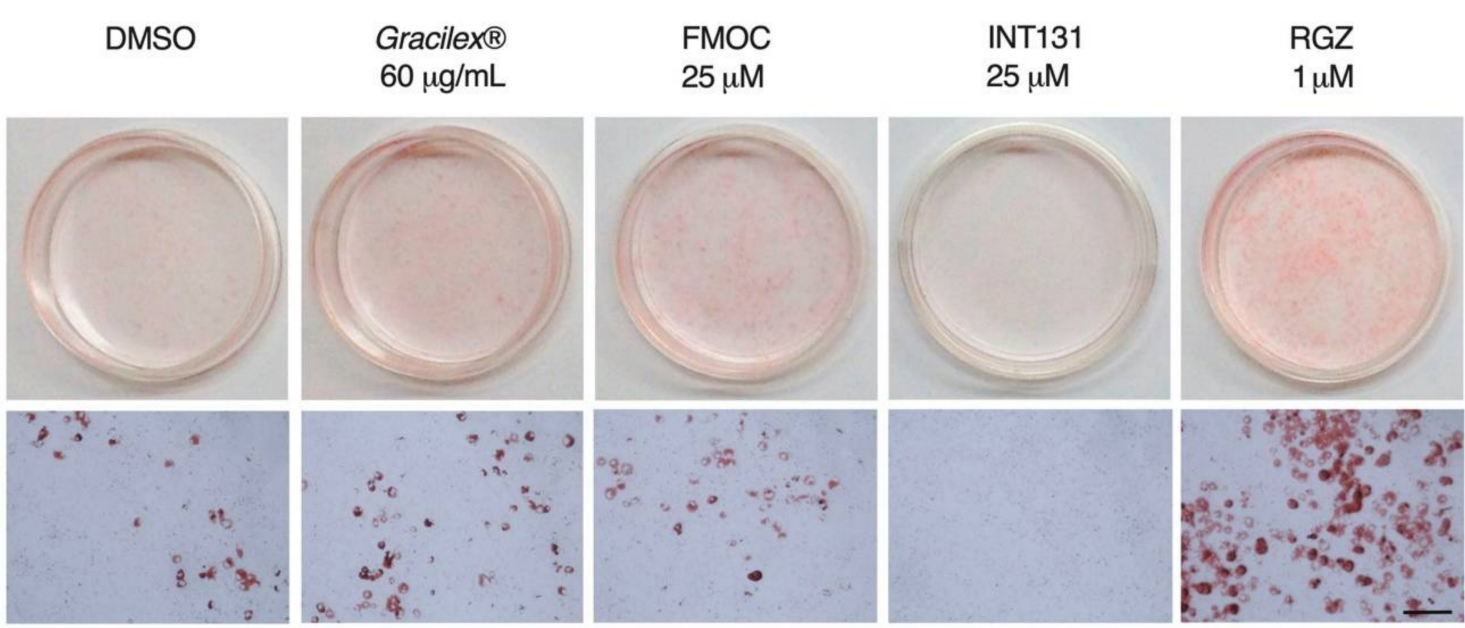

B

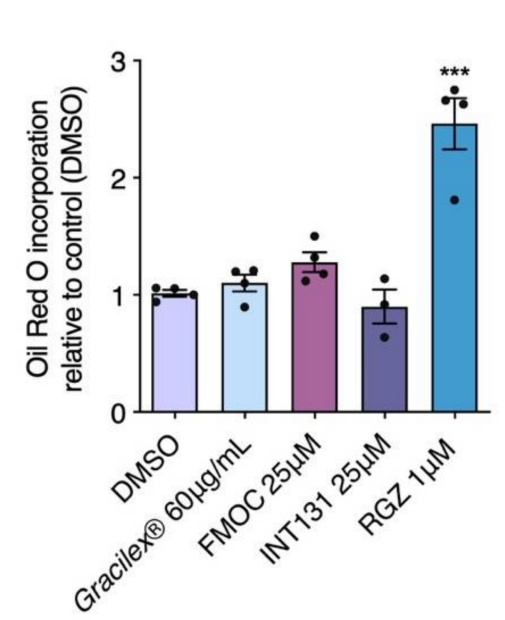

C

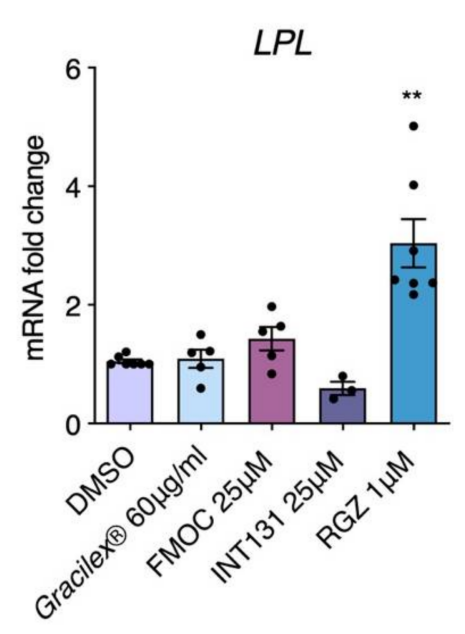

FABP4

Figure 2. Adipogenesis in 3T3-L1 cells induced by rosiglitazone but not Gracilex ${ }^{\circledR}$ or PPAR $\gamma$ SPPARMs, FMOC-Leu (FMOC), and INT131. First, (A) 3T3-L1 preadipocytes were cultured with or without PPAR $\gamma$ agonist FMOC-Leu and INT131 (25 $\mu$ M), rosiglitazone $(\mathrm{RGZ}, 1 \mu \mathrm{M})$, and Gracilex ${ }^{\circledR}(60 \mu \mathrm{g} / \mathrm{mL})$ as specified in the methodology section. After 10 days of culture initiation, cells were stained with Oil Red $\mathrm{O}$ to label triglycerides, and the plates were photographed. Upper panels: microphotography of $35 \mathrm{~mm}$ plates. Lower panels: higher magnification of differentiated adipocytes stained with Oil Red O. Scale bar, $50 \mu \mathrm{m}$. The (B) quantification of Oil Red O incorporation was measured after cell lysis with isopropanol at a wavelength of $490 \mathrm{~nm}$. Values are expressed as mean relative to that of control cells (treated with DMSO) $\pm \mathrm{SEM}, n=6$, ${ }^{* * *} p<0.001$ (one-way ANOVA and Tukey's post hoc test). The (C) effects of Gracilex ${ }^{\circledR}$ and PPAR $\gamma$ agonists on expression of lipogenic pathway-related genes during differentiation process of mouse 3T3-L1 preadipocytes were measured after 7 days of culture initiation, as indicated in the methodology section. After treatment with each compound, cells were lysed and mRNA levels of LPL and FABP4 genes were measured by qPCR. The graph shows the relative abundance compared to the control (untreated cells, control DMSO). Values are expressed as the mean relative to that of control cells (treated with $\mathrm{DMSO}) \pm \mathrm{SEM}, n=4,{ }^{* *} p<0.01,{ }^{* * *} p<0.001$ (one-way ANOVA and Tukey's post hoc test).

\subsection{Effect of A. Chilense Oleoresin on Metabolic Dysfunction Caused by High-Fat Diet (HFD)-Induced Obesity in Male Mice}

Although there are lean individuals with T2DM, obesity explains $60-80 \%$ of diabetes cases [38-40]. Even though animals do not develop T2DM as humans do, there are appropriate animal models for studying the effects of new natural products such as Gracilex ${ }^{\circledR}$ on the development of T2DM induced by a high-fat diet. Studies indicate that a diet high in saturated fat (and not, for example, rich in sucrose) is the most appropriate for the development of metabolic dysfunction in murine models [64], imitating the 
physiological conditions associated with T2DM in humans, such as insulin resistance [45]. The C57BL/6J strain is a very useful strain for the development of diabetes induced by a high-fat diet (HFD) compared to other strains because it is genetically predisposed to develop obesity $[54,65]$. These animals are an ideal model for studying new therapeutic agents, including natural products, and their potential to modulate this condition [45]. Therefore, we used this model to test the potential use of Gracilex ${ }^{\circledR}$ as a nutraceutical agent to improve HFD-induced insulin and glucose resistance. Initially, we compared body weight gain between a group of HFD-fed C57BL/6J mice and another group fed a normal diet (LFD). After 12 weeks, a significant difference $(p<0.001)$ in body weight was observed between the HFD and LFD groups, and was $27 \%$ greater in the high-calorie diet group than in the group receiving a normal diet (Figure $3 \mathrm{~A}$ ). When we compared biochemical blood parameters in LFD versus HFD mice, significantly increased glucose ( $81.7 \mathrm{vs.} 119.5 \mathrm{mg} / \mathrm{dL}$, respectively) (Figure 3B) and insulin ( 0.29 vs. $0.62 \mathrm{ng} / \mathrm{mL}$, respectively) (Figure 3C) levels were observed, consistent with insulin metabolic dysfunction. Additionally, the plasma adiponectin levels were markedly decreased in the HFD mice compared to the LFD mice ( 3.8 vs. $1.8 \mu \mathrm{g} / \mathrm{mL}$, respectively) (Figure 3D), confirming the parameters described in obese animals with insulin resistance. Finally, as a result of high fat intake, the plasma cholesterol values increased significantly in the HFD compared to LFD mice (121 vs. $152 \mathrm{mg} / \mathrm{dL}$, respectively) (Figure 3E). Taken together, these results indicate the effective induction of the insulin resistance state by HFD intake in mice, which is the condition required to test the effect of Gracilex ${ }^{\circledR}$.

To evaluate whether possible harmful effects of Gracilex ${ }^{\circledR}$ ingestion would be observed in mice, we performed a histopathological study in mice treated for a shorter period of time (15 days). No major changes in the kidney and stomach were found (data not shown). In the liver of mice fed a normal chow diet, we observed moderate glycogen accumulation by PAS staining and no changes in fat accumulation (Supplementary Figure S2A-D). Additionally, no changes in body weight were found (Supplementary Figure S2E). These results suggest no toxic effects were induced by Gracilex ${ }^{\circledR}$.

The HFD-treated mice were then subdivided into four groups, maintained on the HFD and orally treated for 30 days with rosiglitazone at $5 \mathrm{mg} / \mathrm{kg}$ per day and two Gracilex ${ }^{\circledR}$ doses, 90 and $300 \mathrm{mg} / \mathrm{kg}$ per day, or corn oil as a vehicle. After the treatment period, no variations in body weight were observed between subgroups; however, differences between the HFD and LFD groups were maintained (Figure 4A), as demonstrated previously [54]. The analysis of blood parameters at the end of the treatment period showed that the mice receiving the HFD and corn oil maintained a significant increase in glycemia compared with the controls (Figure 4B). In the HFD-fed mice, the group treated with Gracilex ${ }^{\circledR} 300 \mathrm{mg} / \mathrm{kg}$ showed a complete recovery of blood glucose levels, reaching the levels of LFD control mice (Figure 4B). Rosiglitazone and Gracilex ${ }^{\circledR}(90$ and $300 \mathrm{mg} / \mathrm{kg}$ ) were also able to decrease glucose to control levels (Figure $4 \mathrm{~B}$ ). In relation to insulin parameters, the HFD mice treated with Gracilex ${ }^{\circledR}$ at a dose of $300 \mathrm{mg} / \mathrm{kg}$ showed a significant decrease in insulin, reaching values close to $50 \%$ of the concentrations found in the insulin-resistant HFDtreated control group (Figure 4C). However, as expected [55,66], synthetic rosiglitazone promoted a decrease in insulin levels, normalizing this parameter to that observed in the control LFD mice.

Adiponectin levels completely recovered after 30 days of rosiglitazone treatment in the HFD-control mice compared with the HFD-rosiglitazone mice, which was equivalent to the values measured in the LFD control group (Figure 4D). Unexpectedly, Gracilex ${ }^{\circledR}$ at $300 \mathrm{mg} / \mathrm{kg}$ per day had the opposite effect to rosiglitazone, with a significant reduction in adiponectin levels compared the HFD-control mice and HFD-Gracilex ${ }^{\circledR}(300 \mathrm{mg} / \mathrm{kg})$ mice (Figure 4D), which is consistent with the fact that Gracilex ${ }^{\circledR}$ does not induce adipocyte differentiation in 3T3-L1 cells as rosiglitazone does (Figure 2). Finally, plasma cholesterol was not affected by treatment with either rosiglitazone or Gracilex ${ }^{\circledR}$ in the HFD-treated mice (Figure 4E), and this group maintained high levels compared to the mice fed a normal diet. These data demonstrate that Gracilex ${ }^{\circledR}$ improves insulin sensitivity and 
normalizes glucose levels induced by HFD with no alterations in weight gain, despite the reduced levels of circulating adiponectin, which is an adipose tissue-derived hormone that regulates the expansion and healthy function of adipose tissue [67]. According to our studies, it is possible to consider Gracilex ${ }^{\circledR}$ as an alternative source of natural PPAR $\gamma$ ligands with similar properties found in selective PPAR modulators, presenting partial receptor activation that is sufficient for insulin sensitization in HFD-induced metabolic dysfunction with no effect on the promotion of adipocyte differentiation.

A

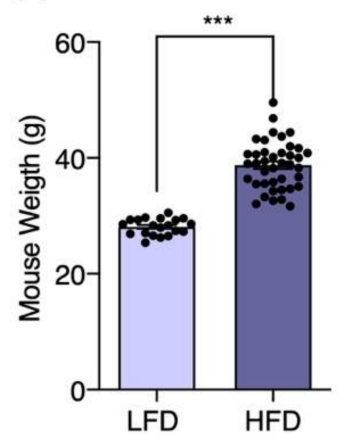

C

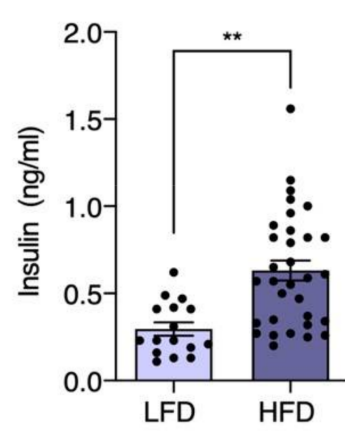

E

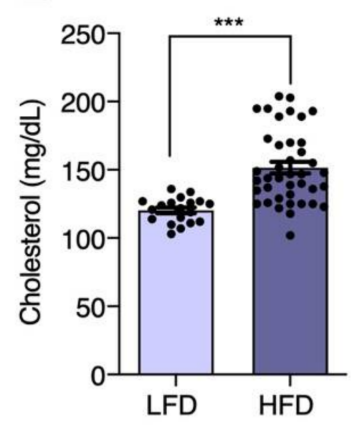

B

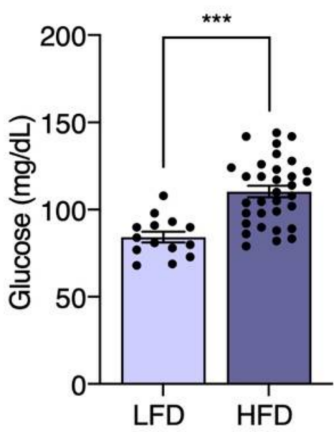

$\mathrm{D}$

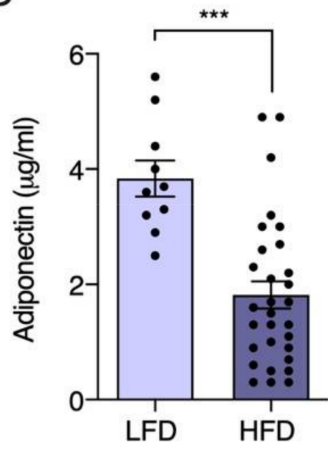

Figure 3. Promotion of weight gain and glucose and insulin resistance in male C57BL/6J mice administered a high-fat diet (HFD). Six-week-old mice were treated for an additional 6 weeks with a low-fat diet (LFD, $n=20)$ and HFD $(n=40)$. The $(A)$ weight recording in groups of mice given LFD and HFD after 6 weeks of treatment. During the whole period, weights were recorded twice a week. Values are expressed as mean recorded weight $\pm \mathrm{SEM},{ }^{* * *} p<0.001$ (unpaired $t$-test). The (B-E) biochemical blood parameters were measured in both groups: plasma glucose (mg/dL), plasma insulin $(\mathrm{ng} / \mathrm{mL})$, plasma adiponectin $(\mu \mathrm{g} / \mathrm{mL})$, and plasma cholesterol $(\mathrm{mg} / \mathrm{dL})$. Values are expressed as mean \pm SEM, and significant differences are highlighted between LFD and HFD groups. ** $p<0.01$ and ${ }^{* * *} p<0.001$ (unpaired $t$-test). 
A

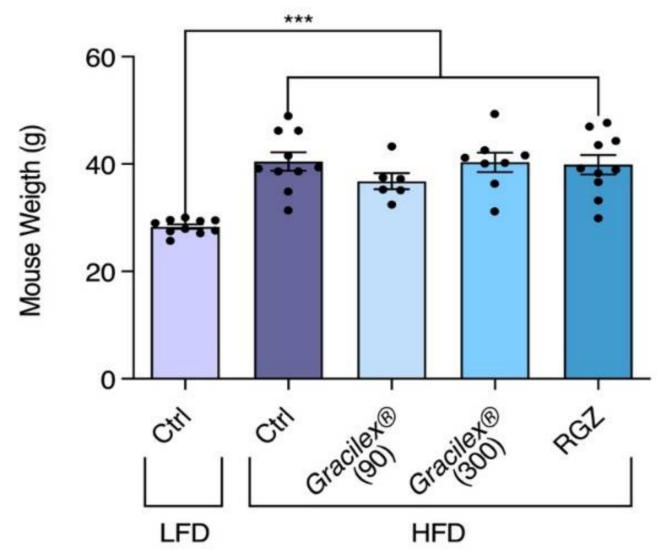

C

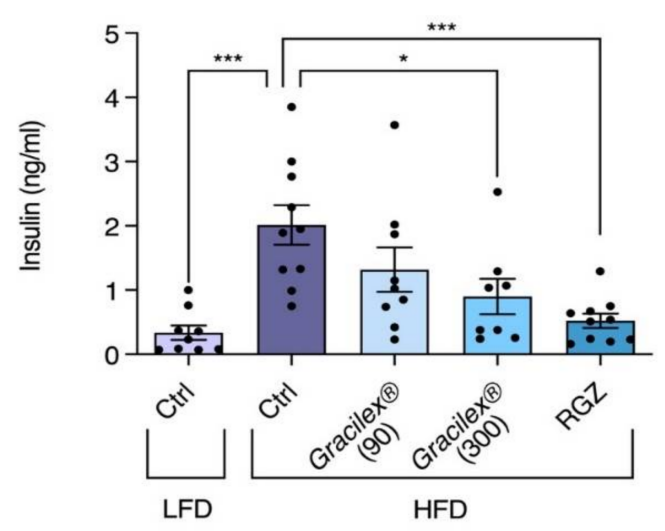

E

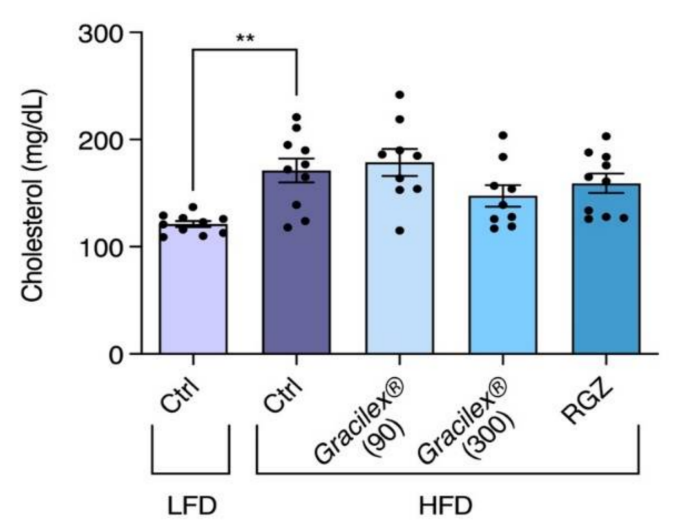

(1)
B

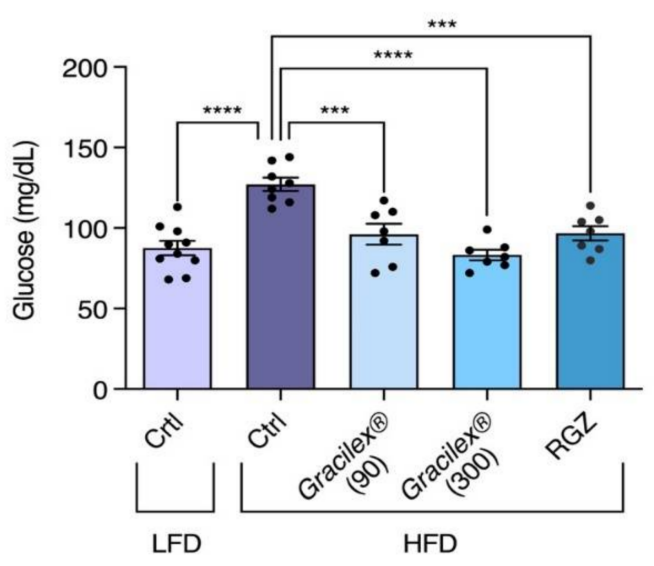

D

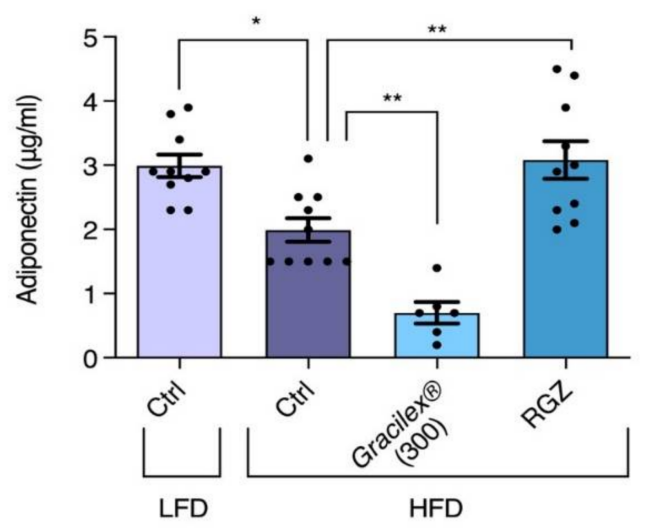

Figure 4. Gracilex ${ }^{\circledR}$ improves altered glucose and insulin parameters in the plasma of male C57BL/6J mice given a HFD. After 6 weeks of LFD and HFD treatment, as indicated in Figure 3, LFD mice continued with the same diet and additional daily treatment with approximately $50 \mu \mathrm{L}$ of corn oil (vehicle for drugs) for 1 month (30 days). HFD-treated mice were divided into 4 groups and continued with the same diet, but 4 daily treatments were given: corn oil (vehicle), 90 and $300 \mathrm{mg} / \mathrm{kg}$ of Gracilex ${ }^{\circledR}$, and rosiglitazone (RGZ, $5 \mathrm{mg} / \mathrm{kg}$ ). During the whole period, weights were recorded twice a week. The (A) comparison of weights at the beginning and end of treatment for each group. Values are expressed as mean \pm SEM, $n=10,{ }^{* * *} p<0.001$ (one-way ANOVA and Tukey's post hoc test). (B-E) After treatment, mice were fasted for $15 \mathrm{~h}$ before taking blood samples; plasma glucose $(\mathrm{mg} / \mathrm{dL})$, plasma insulin $(\mathrm{ng} / \mathrm{mL})$, plasma adiponectin $(\mu \mathrm{g} / \mathrm{mL})$, and plasma cholesterol $(\mathrm{mg} / \mathrm{dL})$ values are shown. Values are expressed as mean $\pm \mathrm{SEM}, n=10$. Significant differences are highlighted between LFD and HFD groups (left panels: ${ }^{* *} p<0.01,{ }^{* * *} p<0.001$, unpaired $t$-test). Significant differences found in post-treatment experiments in HFD group were related to their HFD control. ${ }^{*} p \leq 0.05,{ }^{* *} p<0.01$, and ${ }^{* * *} p<0.001$ (one-way ANOVA and Tukey's post hoc test). 
Species of the Gracilaria genus have already been studied in terms of lipid components by several authors, highlighting the rich and unique composition of sulfoglycolipids, polyunsaturated fatty acids, oxidized fatty acids, pigments, and lipophilic antioxidant molecules $[13,15,68-70]$. An overall analysis of the fatty acid content of Gracilex ${ }^{\circledR}$ is shown in Table 1 as the relative abundance (\%) of total fatty acid methylesters detected by gas chromatography with a flame ionization detector (GC-FID). We found a high content of saturated fatty acids $(51.4 \pm 4.89 \%)$, followed by polyunsaturated $(25.7 \pm 3.12 \%)$ and monounsaturated $(19.6 \pm 2.88 \%)$ fatty acids. The most abundant fatty acids were palmitic acid (C16:0), which contributed $40 \%$ of the total fatty acids analyzed; arachidonic acid (C20:4, n-6) with $21.1 \%$; oleic acid (C18:1, n-9) with $14.13 \%$; myristic acid (C15:0) with $4.4 \%$; and 11-octadecenoic acid (C18:1, n-7) with $4.0 \%$ (Table 1). In general, we found that this distribution is similar to the fatty acid profile reported by Da Costa et al. [13] in their methanolic extract of Gracilaria sp., a red seaweed closely related to A. chilensis. The omega-3 fatty acid content was low, reaching up to $1.22 \%$ of total fatty acids analyzed. In contrast, the total content of omega- 6 fatty acids was higher (Table 1). Arachidonic acid is the precursor of eicosanoids and oxylipins, bioactive lipidic promoters of the defense response in seaweed [12,14]. Most natural and endogenous PPAR $\gamma$ ligands are derived from arachidonic acid metabolization [29]; therefore, the increased abundance in Gracilex ${ }^{\circledR}$ may account for its high PPAR $\gamma$ transactivation capacity.

The nutritional value of red macroalgae is also due to the diverse content of pigments and antioxidants $[69,71,72]$. Consequently, we determined the total antioxidant capacity (TAC) using CUPRAC assay that was compatible with lipophilic antioxidants (such as tocopherols) [47] in Gracilex ${ }^{\circledR}$ and two botanical lipid extracts, spirulin and maqui, produced with dichloromethane extraction as Gracilex ${ }^{\circledR}$. Spirulin and maqui berries are known functional foods with high nutraceutical value. Spirulin is a cyanobacterium with known antioxidant and nutritional beneficial effects [73], and maqui berry (Aristotelia chilensis), a flavonoid-rich berry, is well known for its antioxidant and insulin-sensitizing effects [74]. Table 2 shows that Gracilex ${ }^{\circledR}$ is slightly superior to the other botanical oleoresins, reaching a mean of $430 \mathrm{mg}$ uric acid equivalent per $100 \mathrm{mg}$ of oleoresin. To further explore the antioxidant molecules, we evaluated the content of tocopherols and $\beta$-carotene in Gracilex ${ }^{\circledR}$. As indicated in Table 3, we found high levels of $\beta$-carotene and tocopherols, but did not detect lycopene. The $\beta$-carotene content was approximately $1538 \mu \mathrm{g} / \mathrm{g}$ Gracilex ${ }^{\circledR}$, and the total tocopherol content was $6673 \mu \mathrm{g} / \mathrm{g}$ Gracilex ${ }^{\circledR}$, which was distributed as follows in the different types of tocopherols: $\alpha$-tocopherol $(527.7 \mu \mathrm{g} / \mathrm{g}), \gamma$-tocopherol $(5332.8 \mu \mathrm{g} / \mathrm{g})$, and $\partial$-tocopherol $(2660 \mu \mathrm{g} / \mathrm{g})$. Thus, the antioxidant capacity of Gracilex ${ }^{\circledR}$ is partly due to the high levels of $\beta$-carotene and tocopherols, particularly $\gamma$-tocopherol.

Table 1. Fatty acid composition (relative abundance, \% over total fatty acids) of Agarophyton chilense oleoresin (Gracilex ${ }^{\circledR}$ ). Fatty acids were detected as methyl fatty acids by GC-FID. Results are expressed as mean and standard deviation (SD) of the mean of six independent Gracilex ${ }^{\circledR}$ preparations. Fatty acids were detected as methyl fatty acids by GC-FID. Mean of six lipid extracts produced from independent algal biomass harvested and cultured in different seasons (fall, winter, and summer).

\begin{tabular}{|c|c|c|c|c|}
\hline & Fatty Acid & Chain Length & Mean \% & SD \\
\hline \multirow{8}{*}{ Saturated } & Decanoic Acid & $10: 00$ & 0.760 & 1.1 \\
\hline & Dodecanoic Acid & $12: 00$ & 0.305 & 0.3 \\
\hline & Tridecanoic Acid & $13: 00$ & 0.983 & 0.3 \\
\hline & Tetradecanoic Acid & $14: 00$ & 4.438 & 0.9 \\
\hline & Pentadecanoic Acid & $15: 00$ & 0.440 & 0.3 \\
\hline & Hexadecanoic Acid & $16: 00$ & 40.005 & 5.4 \\
\hline & Heptadecanoic Acid & $17: 00$ & 0.750 & 1.3 \\
\hline & Octadecanoic Acid & 18:00 & 2.683 & 3.0 \\
\hline
\end{tabular}


Table 1. Cont.

\begin{tabular}{|c|c|c|c|c|}
\hline & Fatty Acid & Chain Length & Mean \% & SD \\
\hline & Eicosanoic Acid & 20:00 & 0.152 & 0.08 \\
\hline & Docosanoic Acid & $22: 00$ & 0.238 & 0.05 \\
\hline & Tetracosanoic Acid & 24:00 & 0.127 & 0.08 \\
\hline \multirow{4}{*}{ Mono-Insaturated } & 10-Pentadecaenoic Acid & $15: 1 n-5$ & 1.87 & 1.8 \\
\hline & 9-Hexadecaenoic Acid & $16: 1 \mathrm{n}-7$ & 0.46 & 0.3 \\
\hline & 9-Octadecaenoic Acid & $18: 1$ n-9 & 14.13 & 4.6 \\
\hline & 11-Octadecaenoic Acid & $18: 1 \mathrm{n}-7$ & 4.07 & 1.4 \\
\hline \multirow{5}{*}{$\begin{array}{c}\text { Omega-6 } \\
\text { Polyunsaturated }\end{array}$} & 9,12-Octadecadienoic Acid & $18: 2 n-6$ & 2.87 & 0.81 \\
\hline & 6,9,12-Octadecatrienoic Acid & $18: 3 n-6$ & 0.17 & 0.10 \\
\hline & 11,14-Eicosadienoic Acid & $20: 2 n-6$ & 0.34 & 0.37 \\
\hline & 8,11,14-Eicosatrienoic Acid & $20: 3 n-6$ & 0.47 & 0.09 \\
\hline & 5,8,11,14-Eicosatetraenoic Acid & $20: 4 n-6$ & 21.06 & 3.81 \\
\hline \multirow{4}{*}{$\begin{array}{c}\text { Omega-3 } \\
\text { Polyunsaturated }\end{array}$} & 9,12,15-Octadecatrienoic Acid & $18: 3 n-3$ & 0.390 & 0.42 \\
\hline & 5,8,11,14,17-Eicosapentaenoic Acid & $20: 5 n-3$ & 0.408 & 0.38 \\
\hline & 7,10,13,16,19-Docosapentaenoic Acid & $22: 5 n-3$ & 0.27 & 0.12 \\
\hline & 4,7,10,13,16,19-Docosahexaenoic Acid & $22: 6 n-3$ & 0.125 & 0.04 \\
\hline \multirow{9}{*}{ Other } & \multicolumn{4}{|c|}{ Conjugated Fatty Acids } \\
\hline & Fatty Acid & Chain Length & Mean \% & SD \\
\hline & c9, t11-octadecadienoic Acid & $18: 2$ n-cla & 0.187 & 0.06 \\
\hline & \multicolumn{4}{|c|}{ Trans Fatty Acids } \\
\hline & Fatty Acid & Chain Length & Mean \% & SD \\
\hline & 10-Transpentadecaenoic Acid & $15: 1 \mathrm{n}-5 \mathrm{t}$ & 0.258 & 0.24 \\
\hline & 9-Octadecaenoic Acid & $18: 1 \mathrm{n}-9 \mathrm{t}$ & 1.037 & 1.30 \\
\hline & 11-TransOctadecaenoic Acid & $18: 1 \mathrm{n}-7 \mathrm{t}$ & 0.540 & 0.30 \\
\hline & 9,12-Octadecadienoic Acid & $18: 2 \mathrm{n}-6 \mathrm{tt}$ & 0.11 & 0.04 \\
\hline
\end{tabular}

Table 2. Total antioxidant capacity of oily extracts derived from botanical sources measured with CUPRAC assay. Results were standardized using a uric acid curve according to the manufacturer's instructions and expressed as equivalent of uric acid per $100 \mathrm{mg}$ of oleoresin. Results are expressed as the mean of independent determinations \pm SEM. Gracilex $^{\circledR}(n=7)$, spirulina oleoresin $(n=3)$, and maqui oleoresin $(n=3)$.

\begin{tabular}{cc}
\hline Sample & mg Uric Acid Eq/100mg Oleoresin \\
\cline { 2 - 2 } & Mean \pm SEM \\
\hline Gracilex $^{\circledR}$ & $430 \pm 58.3$ \\
\hline Spirulina oleoresin & $344 \pm 90.6$ \\
\hline Maqui oleoresin & $305 \pm 49.9$ \\
\hline
\end{tabular}


Table 3. Characterization of tocopherol and $\beta$-carotene content of Gracilex ${ }^{\circledR}$. Results are expressed as mean of six independent extract preparations \pm SEM.

\begin{tabular}{cc}
\hline \multirow{2}{*}{ Sample } & $\mu$ g/g of Gracilex ${ }^{\circledR}$ \\
\cline { 2 - 2 } & Mean \pm SEM \\
\hline$\alpha$-Tocopherol & $527.7 \pm 85.3$ \\
\hline$\gamma$-Tocopherol & $5332.8 \pm 1523.3$ \\
\hline$\delta$-Tocopherol & $2660 \pm 397.1$ \\
\hline Total Tocopherols & $6673 \pm 1568.2$ \\
\hline$\beta$-Carotene & $1538 \pm 378.4$ \\
\hline
\end{tabular}

\subsection{Antioxidant Properties of Gracilex ${ }^{\circledR}$}

Considering the high tocopherol and $\beta$-carotene content, we next assessed the ability of Gracilex ${ }^{\circledR}$ to confer antioxidant resistance in vivo. The oxidative stress-sensitive $\mathrm{msra}^{-}$ 1 mutant strain of C. elegans [57] was chosen as a model to evaluate in vivo oxidative stress resistance. Since this strain has been proven to be very sensitive to acute oxidative treatment, it is a powerful tool to assess the physiological consequences of oxidative stress in vivo $[75,76]$. Taking advantage of the autofluorescence of pigments contained in Gracilex ${ }^{\circledR}$, we first evaluated whether the nematodes were able to ingest it in a mixture with dead OP50 bacteria. As shown in Figure 5A, Gracilex ${ }^{\circledR}$ was visualized along the digestive tracts of the nematodes (highlighted by red arrows), indicating that they can ingest it. For antioxidant resistance assays, msra-1 L4 larval stage nematodes were fed for $24 \mathrm{~h}$ with DMSO (control), Gracilex ${ }^{\circledR}$, or N-acetylcysteine (NAC) mixed with dead bacteria. Then, the worms were challenged with a hydrogen peroxide solution and their movement was scored every $10 \mathrm{~min}$. Figure 5B shows the percentage of active nematodes over time after the challenge. After $80 \mathrm{~min}, 60 \%$ of the $\mathrm{msra}-1$ mutants were already inactive compared to $40 \%$ of the nematodes fed Gracilex ${ }^{\circledR}$. From $70-110 \mathrm{~min}$, we consistently found more active nematodes, as shown by the right shift in the survival slope, which was significant at $80 \mathrm{~min}$. Similar behavior was observed in the nematodes previously exposed to $5 \mathrm{mM}$ NAC, a well-known potent antioxidant, which was demonstrated to rescue the unbalance in the redox homeostasis induced by hydrogen peroxide in the msra-1 mutant [57]. The time response curve in Figure 5B showed the highest protection of Gracilex ${ }^{\circledR}$ at $80 \mathrm{~min}$. This time response is in the range of NAC, between 70 to $90 \mathrm{~min}$ after the peroxide challenge (Figure 5C,D). These findings indicated that nematodes fed with Gracilex ${ }^{\circledR}$ had increased resistance against oxidative stress, improving their survival, in agreement with the CUPRAC analysis and the characterization of their antioxidant components. 
A

B

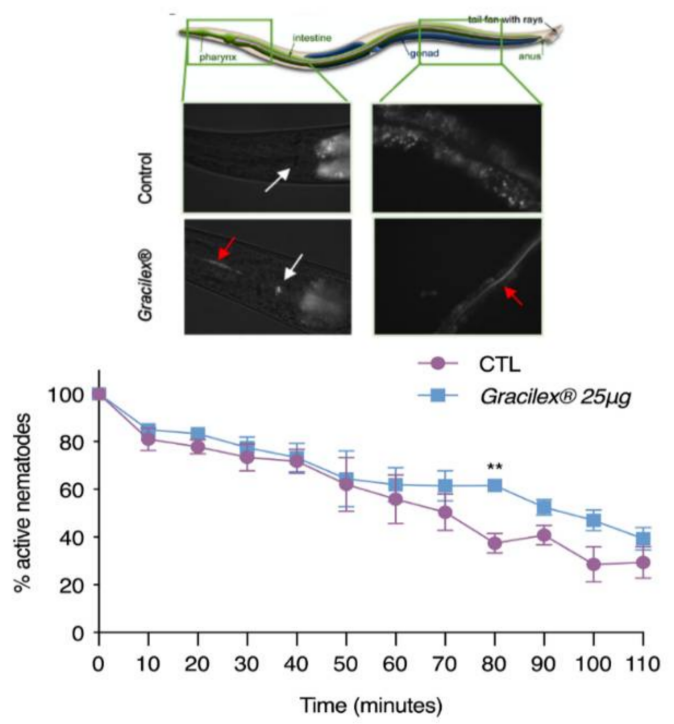

C

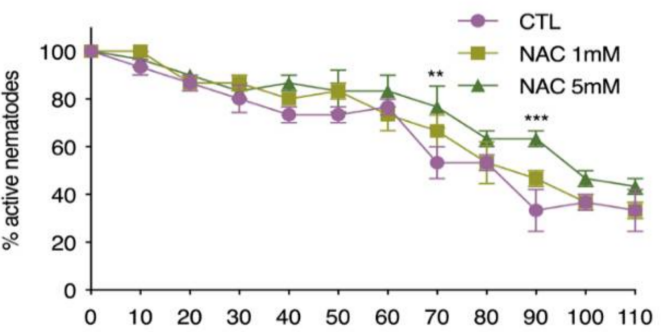

D

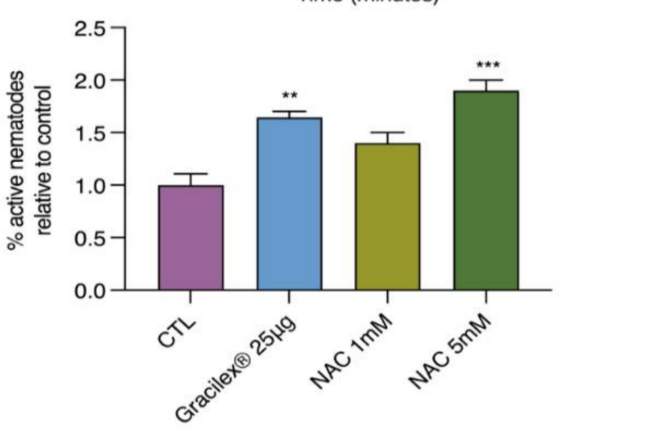

Figure 5. Gracilex ${ }^{\circledR}$ increases oxidative stress resistance in C. elegans challenged with hydrogen peroxide. A (A) representative illustration of whole C. elegans organism from Corsi et al., 2015 [77]. Red autofluorescence of extract was observed along nematode digestive tract visualized under fluorescence microscopy (magnification $400 \times$ ). Gracilex ${ }^{\circledR}$ was dissolved in DMSO and $25 \mu \mathrm{g}$ was mixed with $25 \mu \mathrm{L}$ of dead bacteria and dispersed on $1.5 \mathrm{~mL}$ of agar plate $(35 \mathrm{~mm})$. White arrow shows nematode pharynx; red arrow highlights fluorescent extract inside nematode. Control (CTL) corresponds to adult N2 worm grown under standard conditions. The (B) L4 stage nematodes from the msra- 1 strain were fed Gracilex ${ }^{\circledR}$ for $24 \mathrm{~h}$ then exposed to oxidative stress by 9 mM hydrogen peroxide for up to $110 \mathrm{~min}$. Values are expressed as the mean $(n=5)$ percentage of survival $\pm \mathrm{SEM}$, ** $p<0.01$ (two-way ANOVA with repeated measures and Fisher's LSD test). The (C) same experimental assay was performed as described in (B), but nematodes were fed two concentrations (1 and $5 \mathrm{mM}$ ) of N-acetylcysteine (NAC) dissolved in water. NAC was used as the positive control. Values

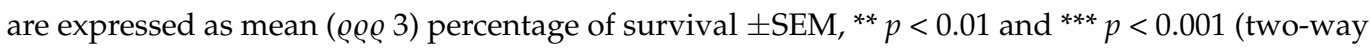
ANOVA with repeated measures and Fisher's LSD test). Significant differences in the percentage of active nematodes were found under treatment with $5 \mathrm{mM}$ NAC compared to the control at 70, 90, and $120 \mathrm{~min}$ after exposure to hydrogen peroxide. The (D) time points where maximum protection effect was observed in B and C were plotted relative to each control ${ }^{* *} p<0.01$ and ${ }^{* * *} p<0.001$ (one-way ANOVA and Tukey's post hoc test) to facilitate comparison. 


\section{Discussion}

Interest in the study of natural bioactive molecules able to activate PPAR $\gamma$ has grown over the years due to the importance of the physiological processes that these receptors regulate and the side effects caused by pharmacological PPAR $\gamma$ drugs. This interest is parallel to an increase in the study of the biomedical potential of seaweed due to the large amount of bioactive molecules that they possess [9,78-80]. The study of the lipid components of $A$. chilense and other closely related red seaweeds demonstrated the presence of PUFAs and eicosanoids [14,16,27]; however, whether the lipids present in the Agarophyton genus were able to activate PPAR $\gamma$ and had insulin sensitizer and antioxidant effects in vivo was unknown. Here, we demonstrated that Gracilex ${ }^{\circledR}$ includes ligands that are able to activate PPAR $\gamma$ at a similar level to that observed with the SPPARMs FMOC-Leu and INT131. In addition, we found a beneficial effect of Gracilex ${ }^{\circledR}$ on insulin sensitization in a mouse model of HFD-induced metabolic disorder with a lack of some of the side effects described for the full agonist rosiglitazone on adipose differentiation.

PPAR $\gamma$ is a lipid sensor of the nutritional and metabolic status of an organism [78]. As a lipid sensor, this receptor is activated by structurally diverse lipophilic substances because the PPAR $\gamma$ ligand-binding pocket is the largest among the nuclear receptors, allowing entry and binding of up to two different molecules in a covalent or noncovalent manner [81-84]. Our first goal was to evaluate whether the lipids present in Gracile ${ }^{\circledR}$ were able to activate PPAR $\gamma$ by comparing it with the full agonist rosiglitazone and two synthetic SPPARMs, FMOC-Leu and INT131 [62,85]. The magnitude of the transcriptional induction of PPAR $\gamma$ achieved by Gracilex ${ }^{\circledR}$ was similar to that observed for SPPARM agonists, revealing, as the first finding, that Gracilex ${ }^{\circledR}$ possesses SPPARM-like ligands. The fact that similar induction of PPAR $\gamma$ transcriptional activity was induced in two different cell lines (Figure 1) with a dose-dependent response suggests that the main bioactive molecules are already present in the extract and that the intrinsic cell metabolism may not undergo further modifications.

Natural extracts presenting PPAR $\gamma$ agonist activity were reported and reviewed extensively by Wang et al. [37]. In a broad screening of extracts derived from 71 plant species, almost $40 \%$ (28 extracts) presented PPAR $\alpha$ or PPAR $\gamma$ activity. However, whether this represents insulin sensitizer activity or antioxidant activity in vivo was not evaluated. In agreement with our findings, greater biological activity was found in extracts produced with dichloromethane than in those obtained with methanol [80], suggesting that the putative PPAR ligands are more easily extracted with apolar solvents. Similar screening was performed by Kim et al. [86] using different macroalgae and methanol/ethyl acetate extractions. They found that the extract from Sargassum yezoense, a brown seaweed, showed the strongest potency for PPAR $\alpha / \gamma$ transcriptional response in a PPRE-based transcriptional assay. According to their studies, the increased PPAR activity was explained by the presence of sarquinoic and sargahydroquinoic acids that could increase adipocyte differentiation of 3T3-L1 cells, which is an unwanted side effect of natural derived ligands expected to be used in diabetes, since this feature is associated with weight gain in T2DM patients [87]. Gracilex ${ }^{\circledR}$ not only induced partial PPAR $\gamma$ activation similar to SPPARMs, but also improved insulin sensitivity and normalized glucose levels with no alterations in weight gain, and did not promote adipocyte differentiation in a classical in vitro model assay.

A recent analysis of $A$. chilense lipids by Honda et al. [14] revealed that glycerolipids comprise the largest proportion of the total lipids (monogalactosyldiacylglycerol and phosphatidylcholine), carrying mostly a combination of arachidonic and palmitic acids (20:4n-6/16:0) in their structure. In agreement with this study, our analysis of the fatty acid profile of Gracilex ${ }^{\circledR}$ showed that palmitic and arachidonic acids were the most abundant fatty acids, representing 40 and $21.1 \%$, respectively. Our findings also agree with a recent report on the fatty acid profile of the related red macroalga Gracilaria spp. [13]. The involvement of these fatty acids and their metabolites in the ability of Gracilex ${ }^{\circledR}$ to induce PPAR $\gamma$ activation is currently unknown and under investigation in our laboratory. Therefore, 
the biological activities that we describe in this work cannot be directly attributed to an increase in the transcriptional activity of PPAR $\gamma$.

One of the central pathologies in metabolic syndrome is insulin resistance, an event that occurs before T2DM. The development of this pathology directly correlates with overweight and obesity; indeed, obesity explains $60-80 \%$ of diabetes cases $[88,89]$. Here, we provide evidence that Gracilex ${ }^{\circledR}$ treatment might be of benefit for overweight patients with insulin resistance, although its effectiveness in humans requires further investigation. Oral treatment of HFD-fed mice with Gracilex ${ }^{\circledR}$ for one month showed a notable decrease in glucose and insulin levels in the blood altered by the HFD at the $300 \mathrm{mg} / \mathrm{kg}$ dose, similar to rosiglitazone at $5 \mathrm{mg} / \mathrm{kg}$. Rosiglitazone increased adiponectin levels, as expected [90]. On the contrary, Gracilex ${ }^{\circledR}$ significantly decreased adiponectin levels in HFD-fed mice compared to HFD-fed control mice.

These findings have several interpretations, first, it is possible that natural lipids directly activate PPAR $\gamma$ similar to SPPARMs; however, this possibility was not evaluated in our study and deserves further investigation. Moreover, the anti-oxidant effect of Gracilex ${ }^{\circledR}$ (see below) may contribute to the improvement observed in metabolic dysfunction since it is known that the generation of reactive oxygen species contributes to the progression of T2DM [91].

On the other hand, this finding indicates that the beneficial effect of Gracilex ${ }^{\circledR}$ is not due to the reported capacity of PPAR $\gamma$ agonists to increase adiponectin levels [90]. Adiponectin is a hormone secreted by adipose tissue and has autocrine and endocrine actions with reported global insulin sensitizer effects [67]. Nonetheless, adiponectin increases the growth of fat tissue, and the overexpression of adiponectin in 3T3-L1 cells increases lipid storage and adipogenesis [92]. Thus, the limited capacity of Gracilex ${ }^{\circledR}$ to increase adipocyte differentiation and accumulation of triglycerides measured by Oil Red O staining in 3T3-L1 cells correlates with the decreased adiponectin levels in vivo induced by Gracilex ${ }^{\circledR}$ in HFD-fed mice. Further experiments studying the genetic programs and transcriptomes in 3T3-L1 cells and adipose tissue from HFD-fed mice treated with the vehicle and Gracilex ${ }^{\circledR}$ will help elucidate this issue [93].

As a source of multiple types of chemical molecules, Gracilex ${ }^{\circledR}$ showed antioxidant activity, as was previously reported in diverse algae-derived extracts. While aqueous extracts have been characterized in depth for either their in vivo activity or their antioxidant components (such as phenols and polyphenols, amino acid-like mycosporines, and sulfated polysaccharides), scarce information exists for the apolar organic-produced fraction, like the one we produced in this study. In the red seaweed Gracilaria blodgetti, a chloroform extract could decrease the oxidative stress induced in leukocytes [94-97]. These results indicate that apolar extracts can be a source of antioxidants for biological membranes.

Depending on the type of alga, solvent used, and season of harvest, a majority or minority of antioxidant components and their activities can be redistributed between polar or apolar fractions $[11,98]$. Difficulties in determining the in vitro capacity of apolar extracts or molecules through classical methods are well known, and more than one assay should be used to confirm their antioxidant potential $[99,100]$. Considering the few alternative methods for determining antioxidant capacity in oleoresins, in addition to the in vitro CUPRAC method, we evaluated the in vivo antioxidant capacity of Gracilex ${ }^{\circledR}$ using a mutant strain of C. elegans that is sensitive to oxidative stress [57]. We found that nematodes fed Gracilex ${ }^{\circledR}$ were protected against exposure to hydrogen peroxide at a similar magnitude as that given by $\mathrm{N}$-acetylcysteine treatment, reflected by an increase in nematode survival. $\mathrm{N}$-acetylcysteine is a source of glutathione production, and has been shown to prevent reactive oxygen species generation [77] and increase oxidative stress protection in C. elegans [76]. Therefore, it was an appropriate positive control for our experiments. These results correlate with high content of tocopherols and $\beta$-carotene, well-known antioxidants that reduce lipid peroxidation, in Gracilex ${ }^{\circledR}$ [101-103]. 


\section{Conclusions}

Altogether, our results indicate that Gracilex ${ }^{\circledR}$, an oleoresin produced using organic solvent extraction from the red macroalgae A. chilense, contains natural PPAR $\gamma$ ligands that increase PPAR $\gamma$ transcriptional activity. Like SPPARMs, Gracilex ${ }^{\circledR}$ did not induce preadipocyte differentiation like the PPAR $\gamma$ receptor full agonist rosiglitazone. Furthermore, HFD mice fed Gracilex ${ }^{\circledR}$ showed normalization of glucose and insulin parameters altered by the diet without increased adiponectin. This result was consistent with the idea that the natural lipids present in Gracilex ${ }^{\circledR}$ act as SPPARM-like agonists of PPAR $\gamma$. However, direct evidence that Gracilex ${ }^{\circledR}$ exerts its biological effects through PPAR $\gamma$ activation warrants future research. Moreover, Gracilex ${ }^{\circledR}$ showed high concentrations of tocopherols and $\beta$-carotene, which correlated with the antioxidant effect in vivo using a C. elegans model of oxidative stress. Therefore, antioxidant activities may also contribute to the normalization of insulin and glucose parameters altered by the HFD. Altogether, our results indicate that Gracilex ${ }^{\circledR}$ represents a good source of natural PPAR $\gamma$ ligands and antioxidants with the potential to mitigate metabolic disorders. Nevertheless, its validation in humans is required to ensure its high nutritional value.

Patents: The methodology to prepare Gracilex ${ }^{\circledR}$ is fully described in the patent application WO/2014/ 186913. "Method for the preparation of an oleoresin originating from a red alga that maintains the capacity to induce the transcriptional activity of the nuclear receptor PPAR-gamma". PCT/CL2013/ 000031 Pontificia Universidad Católica de Chile. Inventors: Bronfman Miguel, Bronfman Francisca, Pinto Claudio, Pissani Claudia, Paredes Martínez, and María José.

Supplementary Materials: The following are available online at https:/ / www.mdpi.com/article/10 $.3390 /$ nu13061828/s1, Figure S1: Cell viability of PC12 and 3T3 cells after treatment with PPAR $\gamma$ agonists and A. chilense oleoresin; Figure S2: Histological analysis of liver and weight measurements after chronic treatment with $\mathrm{A}$. chilense oleoresin in mice fed a normal chow diet.

Author Contributions: C.P., K.F. and F.C.B. conceptualized the study; C.P. conducted the mouse studies. The cell studies were performed by C.P., G.L., C.G., Y.S., and L.L; preparation of the A. chilense oleoresin was performed by C.P., G.L., V.B., L.L., and M.R.I. The availability of $A$. chilense biomass was made possible by F.C. and L.C.-P.; V.B. performed CUPRAC antioxidant determination. M.R.I. and R.A. performed C. elegans studies. Experiments were supervised by K.F., R.A., L.C.-P. and F.C.B.; K.F. and F.C.B. prepared the original draft. Review and editing were the work of F.C.B., K.F., L.C.-P., and R.A. All authors have read and agreed to the published version of the manuscript.

Funding: Agencia Nacional de Investigación y Desarrollo (ANID) project FONDEF\#ID16I10185 (FCB) and Basal Center of Excellence in Science and Technology (PIA BASAL AFB170005) (FCB). CORFO “Consorcio tecnológico desarrollo sinérgico de Ingredientes Funcionales y Aditivos Funcionales IFAN" 16PTECAI-66648 (FCB and LCP), DGI-UNAB (DI-01-21/NUC) (FCB and LCP) and ANID PIA/BASAL FB0002 (LCP).

Institutional Review Board Statement: The study was conducted according to the guidelines of the Declaration of Helsinki, and approved by the biosafety and bioethics committee of the Pontificia Universidad Católica de Chile (project FONDEF\#DO811031 started the first of January 2010). All animal procedures were conducted according to the Chilean National Agency of Research and Development (ANID) guidelines for animal experimentation.

Informed Consent Statement: Not applicable.

Data Availability Statement: Not applicable.

Conflicts of Interest: The authors declare no conflict of interest.

\section{References}

1. Gurgel, C.F.D.; Norris, J.N.; Schmidt, W.E.; Le, H.N.; Fredericq, S. Systematics of the Gracilariales (Rhodophyta) including new subfamilies, tribes, subgenera, and two new genera, Agarophyton gen. nov. and Crassa gen. nov. Phytotaxa 2018, 374, 1-23. [CrossRef]

2. Dillehay, T.D.; Ramirez, C.; Pino, M.; Collins, M.B.; Rossen, J.; Pino-Navarro, J.D. Monte Verde: Seaweed, food, medicine, and the peopling of South America. Science 2008, 320, 784-786. [CrossRef] 
3. Bird, C.J.; McLachlan, J.; De Oliveira, E.C. Gracilaria chilensis sp.nov. (Rhodophyta, Gigartinales), from Pacific South America. Can. J. Bot. 1986, 64, 2928-2934. [CrossRef]

4. Guillemin, M.-L.; Faugeron, S.; Destombe, C.; Viard, F.; Correa, J.A.; Valero, M. Genetic variation in wild and cultivated populations of the haploid-Diploid red alga Gracilaria chilensis: How farming practices favor asexual reproduction and heterozigosity. Evolution 2008, 62, 1500-1519. [CrossRef]

5. Huanel, O.R.; Nelson, W.A.; Robitzch, V.; Mauger, S.; Faugeron, S.; Preuss, M.; Zuccarello, G.C.; Guillemin, M. Comparative phylogeography of two Agarophyton species in the New Zealand archipelago. J. Phycol. 2020, 56, 1575-1590. [CrossRef] [PubMed]

6. Robitzch, V.; Arakaki, N.; Mauger, S.; Rojas, J.C.Z.; Guillemin, M.-L. Stranded alone: The first reported Peruvian population of Agarophyton chilensis is a single-male's clone. Algal Res. 2019, 41, 101527. [CrossRef]

7. Armisen, R. World-wide use and importance of Gracilaria. Environ. Boil. Fishes 1995, 7, 231-243. [CrossRef]

8. Torres, P.; Santos, J.P.; Chow, F.; dos Santos, D.Y. A comprehensive review of traditional uses, bioactivity potential, and chemical diversity of the genus Gracilaria (Gracilariales, Rhodophyta). Algal Res. 2019, 37, 288-306. [CrossRef]

9. Hafting, J.T.; Craigie, J.S.; Stengel, D.B.; Loureiro, R.R.; Buschmann, A.H.; Yarish, C.; Edwards, M.D.; Critchley, A.T. Prospects and challenges for industrial production of seaweed bioactives. J. Phycol. 2015, 51, 821-837. [CrossRef] [PubMed]

10. Ganesan, A.R.; Tiwari, U.; Rajauria, G. Seaweed nutraceuticals and their therapeutic role in disease prevention. Food Sci. Hum. Wellness 2019, 8, 252-263. [CrossRef]

11. Francavilla, M.; Franchi, M.; Monteleone, M.; Caroppo, C. The red seaweed Gracilaria gracilis as a multi products source. Mar. Drugs 2013, 11, 3754-3776. [CrossRef]

12. Weinberger, F.; Lion, U.; Delage, L.; Kloareg, B.; Potin, P.; Beltrán, J.; Flores, V.; Faugeron, S.; Correa, J.; Pohnert, G. Up-regulation of lipoxygenase, phospholipase, and pxylipin-production in the induced chemical defense of the red alga Gracilaria chilensis against epiphytes. J. Chem. Ecol. 2011, 37, 677-686. [CrossRef]

13. Da Costa, E.; Melo, T.; Moreira, A.S.P.; Bernardo, C.; Helguero, L.; Ferreira, I.; Cruz, M.T.; Rego, A.M.; Domingues, P.; Calado, R.; et al. Valorization of lipids from Gracilaria sp. through lipidomics and decoding of antiproliferative and anti-inflammatory activity. Mar. Drugs 2017, 15, 62. [CrossRef] [PubMed]

14. Honda, M.; Ishimaru, T.; Itabashi, Y.; Vyssotski, M. Glycerolipid composition of the red macroalga Agarophyton chilensis and comparison to the closely related Agarophyton vermiculophyllum producing different types of eicosanoids. Mar. Drugs 2019, 17, 96. [CrossRef] [PubMed]

15. Tsai, C.-J.; Pan, B.S. Identification of sulfoglycolipid bioactivities and characteristic fatty acids of marine macroalgae. J. Agric. Food Chem. 2012, 60, 8404-8410. [CrossRef]

16. Lion, U.; Wiesemeier, T.; Weinberger, F.; Beltrán, J.; Flores, V.; Faugeron, S.; Correa, J.; Pohnert, G. Phospholipases and galactolipases trigger oxylipin-mediated wound-activated defence in the red alga Gracilaria chilensis against epiphytes. ChemBioChem 2006, 7, 457-462. [CrossRef] [PubMed]

17. Barbosa, M.; Valentão, P.; Andrade, P.B. Biologically active oxylipins from enzymatic and nonenzymatic routes in macroalgae. Mar. Drugs 2016, 14, 23. [CrossRef]

18. Rempt, M.; Weinberger, F.; Grosser, K.; Pohnert, G. Conserved and species-specific oxylipin pathways in the wound-activated chemical defense of the noninvasive red alga Gracilaria chilensis and the invasive Gracilaria vermiculophylla. Beilstein J. Org. Chem. 2012, 8, 283-289. [CrossRef] [PubMed]

19. Di Costanzo, F.; Di Dato, V.; Ianora, A.; Romano, G. Prostaglandins in marine organisms: A review. Mar. Drugs 2019, 17, 428. [CrossRef]

20. Itoh, T.; Fairall, L.; Amin, K.; Inaba, Y.; Szanto, A.; Bálint, B.L.; Nagy, L.; Yamamoto, K.; Schwabe, J.W.R. Structural basis for the activation of PPAR $\gamma$ by oxidized fatty acids. Nat. Struct. Mol. Biol. 2008, 15, 924-931. [CrossRef]

21. Keller, H.; Dreyer, C.; Medin, J.; Mahfoudi, A.; Ozato, K.; Wahli, W. Fatty acids and retinoids control lipid metabolism through activation of peroxisome proliferator-activated receptor-retinoid X receptor heterodimers. Proc. Natl. Acad. Sci. USA 1993, 90, 2160-2164. [CrossRef]

22. Yu, K.; Bayona, W.; Kallen, C.B.; Harding, H.P.; Ravera, C.P.; McMahon, G.; Brown, M.; Lazar, M.A. Differential activation of peroxisome proliferator-activated receptors by eicosanoids. J. Biol. Chem. 1995, 270, 23975-23983. [CrossRef] [PubMed]

23. Grygiel-Górniak, B. Peroxisome proliferator-activated receptors and their ligands: Nutritional and clinical implications-A review. Nutr. J. 2014, 13, 17. [CrossRef] [PubMed]

24. Chandra, V.; Huang, P.; Hamuro, Y.; Raghuram, S.; Wang, Y.; Burris, T.P.; Rastinejad, F. Structure of the intact PPAR- $\gamma-R X R-\alpha$ nuclear receptor complex on DNA. Nat. Cell Biol. 2008, 456, 350-356. [CrossRef]

25. Ahmadian, M.; Suh, J.M.; Hah, N.; Liddle, C.; Atkins, A.R.; Downes, M.; Evans, R.M. PPAR $\gamma$ signaling and metabolism: The good, the bad and the future. Nat. Med. 2013, 19, 557-566. [CrossRef]

26. Hong, F.; Xu, P.; Zhai, Y. The opportunities and challenges of peroxisome proliferator-activated receptors ligands in clinical drug discovery and development. Int. J. Mol. Sci. 2018, 19, 2189. [CrossRef] [PubMed]

27. Kliewer, S.A.; Sundseth, S.S.; Jones, S.A.; Brown, P.J.; Wisely, G.B.; Koble, C.S.; Devchand, P.; Wahli, W.; Willson, T.M.; Lenhard, J.M.; et al. Fatty acids and eicosanoids regulate gene expression through direct interactions with peroxisome proliferator-activated receptors alpha and gamma. Proc. Natl. Acad. Sci. USA 1997, 94, 4318-4323. [CrossRef] [PubMed]

28. Nagy, L.; Tontonoz, P.; Alvarez, J.G.; Chen, H.; Evans, R.M. Oxidized LDL regulates macrophage gene expression through ligand activation of PPAR $\gamma$. Cell 1998, 93, 229-240. [CrossRef] 
29. Forman, B.M.; Tontonoz, P.; Chen, J.; Brun, R.P.; Spiegelman, B.M.; Evans, R.M. 15-Deoxy- $\Delta 12,14-$ Prostaglandin J2 is a ligand for the adipocyte determination factor PPAR $\gamma$. Cell 1995, 83, 803-812. [CrossRef]

30. Yamada, H.; Oshiro, E.; Kikuchi, S.; Hakozaki, M.; Takahashi, H.; Kimura, K.-I. Hydroxyeicosapentaenoic acids from the Pacific krill show high ligand activities for PPARs. J. Lipid Res. 2014, 55, 895-904. [CrossRef] [PubMed]

31. Thuillier, P.; Brash, A.R.; Kehrer, J.P.; Stimmel, J.B.; Leesnitzer, L.M.; Yang, P.; Newman, R.A.; Fischer, S.M. Inhibition of peroxisome proliferator-activated receptor (PPAR)-mediated keratinocyte differentiation by lipoxygenase inhibitors. Biochem. J. 2002, 366, 901-910. [CrossRef]

32. Gross, B.; Pawlak, M.; Lefebvre, P.; Staels, B. PPARs in obesity-induced T2DM, dyslipidaemia and NAFLD. Nat. Rev. Endocrinol. 2017, 13, 36-49. [CrossRef] [PubMed]

33. Wang, S.; Dougherty, E.J.; Danner, R.L. PPAR $\gamma$ signaling and emerging opportunities for improved therapeutics. Pharmacol. Res. 2016, 111, 76-85. [CrossRef] [PubMed]

34. Graham, D.J.; Ouellet-Hellstrom, R.; MaCurdy, T.E.; Ali, F.; Sholley, C.; Worrall, C.; Kelman, J.A. Risk of acute myocardial infarction, stroke, heart failure, and death in elderly medicare patients treated with rosiglitazone or pioglitazone. JAMA 2010, 304, 411-418. [CrossRef] [PubMed]

35. Nissen, S.E. Perspective: Effect of rosiglitazone on cardiovascular outcomes. Curr. Cardiol. Rep. 2007, 9, 343-344. [CrossRef] [PubMed]

36. European Medicines Agency. European Medicines Agency Recommended Suspention of Avandia, A.a.A. Available online: http:/ / www.ema.europa.eu/ema/index.jsp?curl=pages/news_and_events/news/2010/09/news_detail_001119.jsp. (accessed on 23 September 2010).

37. Wang, L.; Waltenberger, B.; Pferschy-Wenzig, E.-M.; Blunder, M.; Liu, X.; Malainer, C.; Blazevic, T.; Schwaiger, S.; Rollinger, J.M.; Heiss, E.H.; et al. Natural product agonists of peroxisome proliferator-activated receptor gamma (PPAR $\gamma$ ): A review. Biochem. Pharmacol. 2014, 92, 73-89. [CrossRef]

38. Li, J.; Lian, H. Recent development of single preparations and fixed-dose combination tablets for the treatment of non-insulindependent diabetes mellitus. Arch. Pharmacal Res. 2016, 39, 731-746. [CrossRef]

39. Steffes, M.W.; Sibley, S.; Jackson, M.; Thomas, W. $\beta$-Cell function and the development of diabetes-related complications in the diabetes control and complications trial. Diabetes Care 2003, 26, 832-836. [CrossRef] [PubMed]

40. Luk, A.O.; Lau, E.S.; So, W.-Y.; Ma, R.; Kong, A.P.; Ozaki, R.; Chow, F.C.; Chan, J.C. Prospective study on the incidences of cardiovascular-renal complications in chinese patients with young-onset type 1 and type 2 diabetes. Diabetes Care 2013, 37, 149-157. [CrossRef] [PubMed]

41. Bailey, C.J.; Day, C. The future of new drugs for diabetes management. Diabetes Res. Clin. Pr. 2019, 155, 107785. [CrossRef]

42. Vijan, S. Type 2 diabetes. Ann. Intern. Med. 2015, 162, ITC1. [CrossRef]

43. Patti, A.M.; Giglio, R.V.; Papanas, N.; Rizzo, M.; Rizvi, A.A. Future perspectives of the pharmacological management of diabetic dyslipidemia. Expert Rev. Clin. Pharmacol. 2019, 12, 129-143. [CrossRef] [PubMed]

44. Wells, M.L.; Potin, P.; Craigie, J.S.; Raven, J.A.; Merchant, S.S.; Helliwell, K.E.; Smith, A.G.; Camire, M.E.; Brawley, S.H. Algae as nutritional and functional food sources: Revisiting our understanding. J. Appl. Phycol. 2017, 29, 949-982. [CrossRef] [PubMed]

45. Asrafuzzaman, C.Y.; Afroz, R.; Kamato, D.; Gray, S.; Little, P.J. Animal models for assessing the impact of natural products on the aetiology and metabolic pathophysiology of Type 2 diabetes. Biomed. Pharmacother. 2017, 89, 1242-1251. [CrossRef] [PubMed]

46. Bronfman, M.; Bronfman, F.C.; Pinto, C.; Pissani, C.; Paredes Martínes, M.J. Method for the Preparation of an Oleoresin Originating From a Red Alga That Maintains the Capacity to Induce the Transcriptional Activity of the Nuclear Receptor PPAR-Gamma. U.S. Patent WO2014186913A1, 27 November 2014.

47. Apak, R.; Güçlü, K.; Demirata, B.; Özyürek, M.; Çelik, S.E.; Bektaşoğlu, B.; Berker, K.I.; Özyurt, D. Comparative evaluation of various total antioxidant capacity assays applied to phenolic compounds with the CUPRAC assay. Molecules 2007, 12, 1496-1547. [CrossRef]

48. Fuenzalida, K.M.; Aguilera, M.C.; Piderit, D.G.; Ramos, P.; Contador, D.; Quiñones, V.; Rigotti, A.; Bronfman, F.C.; Bronfman, M. Peroxisome proliferator-activated receptor $\gamma$ is a novel target of the nerve growth factor signaling pathway in PC12 Cells. J. Biol. Chem. 2005, 280, 9604-9609. [CrossRef]

49. Bai, C.; Schmidt, A.; Freedman, L.P. Steroid hormone receptors and drug discovery: Therapeutic opportunities and assay designs. ASSAY Drug Dev. Technol. 2003, 1, 843-852. [CrossRef]

50. Paguio, A.; Stecha, P.; Wood, K.V.; Fan, F. Improved dual-luciferase reporter assays for nuclear receptors. Curr. Chem. Genom. 2010, 4, 43-49. [CrossRef]

51. Zebisch, K.; Voigt, V.; Wabitsch, M.; Brandsch, M. Protocol for effective differentiation of 3T3-L1 cells to adipocytes. Anal. Biochem. 2012, 425, 88-90. [CrossRef]

52. Kraus, N.A.; Ehebauer, F.; Zapp, B.; Rudolphi, B.; Kraus, B.J.; Kraus, D. Quantitative assessment of adipocyte differentiation in cell culture. Adipocyte 2016, 5, 351-358. [CrossRef]

53. Mosmann, T. Rapid colorimetric assay for cellular growth and survival: Application to proliferation and cytotoxicity assays. J. Immunol. Methods 1983, 65, 55-63. [CrossRef]

54. Almind, K.; Kahn, C.R. Genetic determinants of energy expenditure and insulin resistance in diet-induced obesity in mice. Diabetes 2004, 53, 3274-3285. [CrossRef] 
55. Heydemann, A. An overview of murine high fat diet as a model for type 2 diabetes mellitus. J. Diabetes Res. 2016, $2016,1-14$. [CrossRef] [PubMed]

56. Stiernagle, T. Maintenance of C. Elegans. In WormBook: The Online Review of C.elegans Biology [Internet]; WormBook: Pasadena, CA, USA, 2005-2018. Available online: https:/ /www.ncbi.nlm.gov/books/NBK19649/ (accessed on 11 February 2006).

57. Minniti, A.N.; Arriagada, H.; Zúñiga, S.; Bravo-Zehnder, M.; Alfaro, I.E.; Aldunate, R. Temporal pattern of neuronal insulin release during Caenorhabditis elegans aging: Role of redox homeostasis. Aging Cell 2018, 18, e12855. [CrossRef]

58. Chalfie, M.; Hart, A.C.; Rankin, C.H.; Goodman, M.B. WormBook: The online review of C. Elegans biology [Internet]. WormBook: Pasadena, CA, USA, 2005-2018. Available online: https://www.ncbi.nlm.nih.gov/books/NBK235860/ (accessed on 31 July 2014).

59. Possik, E.; Pause, A. Measuring oxidative stress resistance of Caenorhabditis elegans in 96-well microtiter plates. J. Vis. Exp. 2015, 99, e52746. [CrossRef]

60. Kliewer, S.A.; Forman, B.M.; Blumberg, B.; Ong, E.S.; Borgmeyer, U.; Mangelsdorf, D.J.; Umesono, K.; Evans, R.M. Differential expression and activation of a family of murine peroxisome proliferator-activated receptors. Proc. Natl. Acad. Sci. USA 1994, 91, 7355-7359. [CrossRef] [PubMed]

61. Lee, G.; Elwood, F.; McNally, J.; Weiszmann, J.; Lindstrom, M.; Amaral, K.; Nakamura, M.; Miao, S.; Cao, P.; Learned, R.M.; et al. T0070907, a selective ligand for peroxisome proliferator-activated receptor $\gamma$, functions as an antagonist of biochemical and cellular activities. J. Biol. Chem. 2002, 277, 19649-19657. [CrossRef] [PubMed]

62. Dunn, F.L.; Higgins, L.S.; Fredrickson, J.; DePaoli, A.M. Selective modulation of PPAR $\gamma$ activity can lower plasma glucose without typical thiazolidinedione side-effects in patients with type 2 diabetes. J. Diabetes Complicat. 2011, 25, 151-158. [CrossRef]

63. Green, H.; Kehinde, O. An established preadipose cell line and its differentiation in culture II. Factors affecting the adipose conversion. Cell 1975, 5, 19-27. [CrossRef]

64. Hu, S.; Wang, L.; Yang, D.; Li, L.; Togo, J.; Wu, Y.; Liu, Q.; Li, B.; Li, M.; Wang, G.; et al. Dietary fat, but not protein or carbohydrate, regulates energy intake and causes adiposity in mice. Cell Metab. 2018, 28, 415-431. [CrossRef]

65. Toye, A.A.; Lippiat, J.D.; Proks, P.; Shimomura, K.; Bentley, L.; Hugill, A.; Mijat, V.; Goldsworthy, M.; Moir, L.; Haynes, A.; et al. A genetic and physiological study of impaired glucose homeostasis control in C57BL/6J mice. Diabetology 2005, 48, 675-686. [CrossRef] [PubMed]

66. Soccio, R.E.; Li, Z.; Chen, E.R.; Foong, Y.H.; Benson, K.K.; DiSpirito, J.R.; Mullican, S.E.; Emmett, M.J.; Briggs, E.R.; Peed, L.C.; et al. Targeting PPAR $\gamma$ in the epigenome rescues genetic metabolic defects in mice. J. Clin. Investig. 2017, 127, 1451-1462. [CrossRef]

67. Stern, J.H.; Rutkowski, J.M.; Scherer, P.E. Adiponectin, leptin, and fatty acids in the maintenance of metabolic homeostasis through adipose tissue crosstalk. Cell Metab. 2016, 23, 770-784. [CrossRef]

68. De Almeida, C.L.F.; Falcão, H.D.S.; Lima, G.R.D.M.; Montenegro, C.D.A.; Lira, N.S.; De Athayde-Filho, P.F.; Rodrigues, L.C.; Souza, M.D.F.V.D.; Barbosa-Filho, J.M.; Batista, L.M. Bioactivities from marine algae of the genus Gracilaria. Int. J. Mol. Sci. 2011, 12, 4550-4573. [CrossRef] [PubMed]

69. Schubert, N.; García-Mendoza, E.; Pacheco-Ruiz, I. Carotenoid composition of marine red algae. J. Phycol. 2006, 42, 1208-1216. [CrossRef]

70. Sanz-Pintos, N.; Pérez-Jiménez, J.; Buschmann, A.H.; Vergara-Salinas, J.R.; Pérez-Correa, J.R.; Saura-Calixto, F. Macromolecular antioxidants and dietary fiber in edible seaweeds. J. Food Sci. 2017, 82, 289-295. [CrossRef]

71. Paniagua-Michel, J.; Capa-Robles, W.; Olmos-Soto, J.; Gutierrez-Millan, L.E. The carotenogenesis pathway via the isoprenoid$\beta$-carotene interference approach in a new strain of Dunaliella salina isolated from Baja California Mexico. Mar. Drugs 2009, 7, 45-56. [CrossRef]

72. Gunathilaka, T.L.; Samarakoon, K.W.; Ranasinghe, P.; Peiris, L.D.C. In-vitro antioxidant, hypoglycemic activity, and identification of bioactive compounds in phenol-rich extract from the marine red algae Gracilaria edulis (Gmelin) Silva. Molecules 2019, 24, 3708. [CrossRef]

73. Hoseini, S.; Khosravi-Darani, K.; Mozafari, M.R. Nutritional and medical applications of Spirulina microalgae. Mini Rev. Med. Chem. 2013, 13, 1231-1237. [CrossRef]

74. Sandoval, V.; Femenias, A.; Martínez-Garza, Ú.; Sanz-Lamora, H.; Castagnini, J.M.; Quifer-Rada, P.; Lamuela-Raventós, R.M.; Marrero, P.F.; Haro, D.; Relat, J. Lyophilized Maqui (Aristotelia chilensis) Berry induces browning in the subcutaneous white adipose tissue and ameliorates the insulin resistance in high fat diet-induced obese mice. Antioxidants 2019, 8, 360. [CrossRef] [PubMed]

75. Oh, S.-I.; Park, J.-K.; Park, S.-K. Lifespan extension and increased resistance to environmental stressors by N-Acetyl-L-Cysteine in Caenorhabditis elegans. Clinics 2015, 70, 380-386. [CrossRef]

76. Schulz, T.J.; Zarse, K.; Voigt, A.; Urban, N.; Birringer, M.; Ristow, M. Glucose restriction extends Caenorhabditis elegans life span by inducing mitochondrial respiration and increasing oxidative stress. Cell Metab. 2007, 6, 280-293. [CrossRef]

77. Corsi, A.K. A Transparent window into biology: A primer on Caenorhabditis elegans. WormBook 2015, 1-31. [CrossRef] [PubMed]

78. Hong, F.; Pan, S.; Guo, Y.; Xu, P.; Zhai, Y. PPARs as nuclear receptors for nutrient and energy metabolism. Molecules 2019, 24, 2545. [CrossRef]

79. Guasch, L.; Sala, E.; Mulero, M.; Valls, C.; Salvadó, M.J.; Pujadas, G.; Garcia-Vallvé, S. Identification of PPARgamma partial agonists of natural origin (II): In silico prediction in natural extracts with known antidiabetic activity. PLoS ONE 2013, 8, e55889. [CrossRef] 
80. Vogl, S.; Picker, P.; Mihaly-Bison, J.; Fakhrudin, N.; Atanasov, A.G.; Heiss, E.H.; Wawrosch, C.; Reznicek, G.; Dirsch, V.M.; Saukel, J.; et al. Ethnopharmacological in vitro studies on Austria's folk medicine-An unexplored lore in vitro anti-inflammatory activities of 71 Austrian traditional herbal drugs. J. Ethnopharmacol. 2013, 149, 750-771. [CrossRef]

81. Nolte, R.T.; Wisely, G.B.; Westin, S.; Cobb, J.E.; Lambert, M.H.; Kurokawa, R.; Rosenfeld, M.G.; Willson, T.M.; Glass, C.K.; Milburn, M.V. Ligand binding and co-activator assembly of the peroxisome proliferator-activated receptor- $\gamma$. Nat. Cell Biol. 1998, 395, 137-143. [CrossRef]

82. Kroker, A.J.; Bruning, J.B. Review of the structural and dynamic mechanisms of PPAR $\gamma$ partial agonism. PPAR Res. 2015, 2015, 1-15. [CrossRef] [PubMed]

83. Uppenberg, J.; Svensson, C.; Jaki, M.; Bertilsson, G.; Jendeberg, L.; Berkenstam, A. Crystal structure of the ligand binding domain of the human nuclear receptor PPAR $\gamma$. J. Biol. Chem. 1998, 273, 31108-31112. [CrossRef]

84. Waku, T.; Shiraki, T.; Oyama, T.; Maebara, K.; Nakamori, R.; Morikawa, K. The nuclear receptor PPAR $\gamma$ individually responds to serotonin- and fatty acid-metabolites. EMBO J. 2010, 29, 3395-3407. [CrossRef] [PubMed]

85. Rocchi, S.; Picard, F.; Vamecq, J.; Gelman, L.; Potier, N.; Zeyer, D.; Dubuquoy, L.; Bac, P.; Champy, M.-F.; Plunket, K.D.; et al. A Unique PPAR $\gamma$ Ligand with Potent Insulin-Sensitizing yet Weak Adipogenic Activity. Mol. Cell 2001, 8, 737-747. [CrossRef]

86. Kim, S.-N.; Choi, H.Y.; Lee, W.; Park, G.M.; Shin, W.S.; Kim, Y.K. Sargaquinoic acid and sargahydroquinoic acid from Sargassum yezoense stimulate adipocyte differentiation through PPAR $\alpha / \gamma$ activation in 3T3-L1 cells. FEBS Lett. 2008, 582, 3465-3472. [CrossRef]

87. Raskin, P. Why insulin sensitizers but not secretagogues should be retained when initiating insulin in type 2 diabetes. Diabetes Metabol. Res. Rev. 2007, 24, 3-13. [CrossRef] [PubMed]

88. Chan, J.M.; Rimm, E.B.; Colditz, G.A.; Stampfer, M.J.; Willett, W.C. Obesity, fat distribution, and weight gain as risk factors for clinical diabetes in men. Diabetes Care 1994, 17, 961-969. [CrossRef] [PubMed]

89. Shai, I.; Jiang, R.; Manson, J.E.; Stampfer, M.J.; Willett, W.C.; Colditz, G.A.; Hu, F.B. Ethnicity, obesity, and risk of type 2 diabetes in women: A 20-year follow-up study. Diabetes Care 2006, 29, 1585-1590. [CrossRef] [PubMed]

90. Choi, J.H.; Banks, A.S.; Estall, J.L.; Kajimura, S.; Boström, P.; Laznik, D.; Ruas, J.L.; Chalmers, M.J.; Kamenecka, T.M.; Blüher, M.; et al. Anti-diabetic drugs inhibit obesity-linked phosphorylation of PPAR $\gamma$ by Cdk. Nat. Cell Biol. 2010, 466, 451-456. [CrossRef]

91. Kaneto, H.; Katakami, N.; Matsuhisa, M.; Matsuoka, T.-A. Role of reactive oxygen species in the progression of type 2 diabetes and atherosclerosis. Mediat. Inflamm. 2010, 2010, 1-11. [CrossRef] [PubMed]

92. Fu, Y.; Luo, N.; Klein, R.L.; Garvey, W.T. Adiponectin promotes adipocyte differentiation, insulin sensitivity, and lipid accumulation. J. Lipid Res. 2005, 46, 1369-1379. [CrossRef]

93. Astapova, O.; Leff, T. Adiponectin and PPAR $\gamma$. Vitam. Hormon. 2012, 90, 143-162. [CrossRef]

94. Zhang, Q.; Li, N.; Liu, X.; Zhao, Z.; Li, Z.; Xu, Z. The structure of a sulfated galactan from Porphyra haitanensis and its in vivo antioxidant activity. Carbohydr. Res. 2004, 339, 105-111. [CrossRef]

95. Lin, H.-C.T.; Tsai, W.-S.; Chiu, T.-H. Antioxidant properties of seven cultivated and natural edible seaweed extracts from Taiwan. J. Aquat. Food Prod. Technol. 2012, 21, 248-264. [CrossRef]

96. Batista-Gonzalez, A.E.; Silva, A.M.D.O.E.; Vidal-Novoa, A.; Pinto, J.R.; Mancini, D.A.P.; Mancini-Filho, J. Analysis of in vitro and in vivo antioxidant properties of hydrophilic fractions from the seaweed halimeda monile 1. J. Food Biochem. 2011, 36, 189-197. [CrossRef]

97. Murakami, A.; Ishida, H.; Kobo, K.; Furukawa, I.; Ikeda, Y.; Yonaha, M.; Aniya, Y.; Ohigashi, H. Suppressive effects of Okinawan food items on free radical generation from stimulated leukocytes and identification of some active constituents: Implications for the prevention of inflammation-associated carcinogenesis. Asian Pac. J. Cancer Prev. 2006, 6, 437-448.

98. Miranda-Delgado, A.M.; Montoya, M.J.; Paz-Araos, M.; Mellado, M.; Villena, J.; Arancibia, P.; Madrid, A.; Jara-Gutierrez, C. Antioxidant and anti-cancer activities of brown and red seaweed extracts from Chilean coasts. Lat. Am. J. Aquat. Res. 2018, 46, 301-313. [CrossRef]

99. Frankel, E.N.; Meyer, A.S. The problems of using one-dimensional methods to evaluate multifunctional food and biological antioxidants. J. Sci. Food Agric. 2000, 80, 16. [CrossRef]

100. Prior, R.L.; Wu, X.; Schaich, K. Standardized methods for the determination of antioxidant capacity and phenolics in foods and dietary supplements. J. Agric. Food Chem. 2005, 53, 4290-4302. [CrossRef]

101. Mueller, L.; Boehm, V. Antioxidant activity of $\beta$-carotene compounds in different in vitro assays. Molecules 2011, 16, 1055-1069. [CrossRef] [PubMed]

102. Niki, E.; Traber, M. A History of vitamin, E. Ann. Nutr. Metab. 2012, 61, 207-212. [CrossRef]

103. Tsuchihashi, H.; Kigoshi, M.; Iwatsuki, M.; Niki, E. Action of $\beta$-Carotene as an antioxidant against lipid peroxidation. Arch. Biochem. Biophys. 1995, 323, 137-147. [CrossRef] 